Review

\title{
Microfluidic Bioreactors for Cellular Microarrays
}

\section{Ronnie G. Willaert * and Katty Goossens}

Structural Biology Brussels, Department of Bioengineering Sciences, Vrije Universiteit Brussel, Pleinlaan 2, 1050 Brussels, Belgium; E-Mail: Katty.Goossens@vub.ac.be

* Author to whom correspondence should be addressed; E-Mail: Ronnie.Willaert@vub.ac.be; Tel.: +32-2-629-1846; Fax: +32-2-629-1963.

Academic Editor: Badal C. Saha

Received: 16 May 2015 / Accepted: 31 July 2015 / Published: 7 August 2015

\begin{abstract}
Living cell microarrays have been combined with microfluidic bioreactors, which provide multiple advantages for multiplex dynamic analyses and high-throughput screening. In the last decade, many developments in this new field have been introduced. The technology has evolved from fixed cell analysis towards living single-cell dynamic systems' biology and high content analyses. The aim of this review is to provide an updated overview of the developments of living cellular microarrays in microfluidic bioreactors. Cell arrays in microfluidic bioreactors constructed with adherent mammalian cells are compared to non-adherent cells (mainly microbial cells). An overview is given on the design and construction of these microfluidic devices with a particular focus on cell patterning techniques. Cell patterning on adhesive micropatterns using techniques such as microcontact printing, microfluidic patterning, dip-pen nanolithography and polymer pen lithography as well as photo-patterning and laser-patterning strategies are discussed. Additionally, developments in mechanical cell patterning methods and robotic cell printing are reviewed. Two-dimensional (2D) as well as recently developed 3D cell arraying are discussed. Finally, cell array microfluidic setups and operation for single-cell types versus cell population variants are illustrated and compared on the basis of some illustrative examples in the field of drug screening, cytotoxicity evaluation, and basic cellular and microbiology research.
\end{abstract}

Keywords: microfluidic bioreactor; cellular arrays; cell patterning; adhesive micropatterns; mechanical cell patterning; robotic cell printing; drug screening; toxicology; cell biology research; microbiology research 


\section{Introduction}

Growing cells in 96-, 384- or 1536-well microtiter plates has miniaturized cell assays. However, as cell collections grow, one will need to further miniaturize cell assays to increase parallelism of cell analysis. To that end, cell microarrays provide an attractive solution, as it could increase the throughput significantly [1]. A cellular microarray consists of a solid support wherein small volumes of different biomolecules and cells can be displayed in defined locations, allowing the multiplexed interrogation of living cells and the analysis of cellular responses [2]. Cellular arrays are relevant to both industry and academia and are emerging as important tools for drug discovery, toxicology, functional genomics, cell biology research and investigation of cellular microenvironments, and microbiology research and bioprocess development. Moreover, they are changing how living-cell experiments are performed, and they are broadly impacting the way we organize our understanding of the cell, its molecular machinery, and its behavior within the context of complex tissues [3]. Also, cell microarrays offer many other advantages over microtiter plates [1]. The main advantage of cell microarrays is the opportunity to measure parameters on hundreds of individual cells and average them, instead of measuring the parameters of a whole cell population. Also, because of extreme miniaturization, only small quantities of expensive reagents, scarce biological samples or rare cells are needed. Moreover, most cell microarrays are implemented on glass slides, which allows a larger range of detection methods to be used. Finally, and more importantly, cell microarrays could enable scientists to study biological questions that were not addressable before.

Microfluidic technology is a powerful tool to study the cell biology by controlling the complete cellular microenvironment. Also, performing high-throughput biological experiments is made possible by combining the miniaturization of macroscopic systems and the possibility of massive parallel processing [4]. Microfluidics is a technology that is characterized by the manipulation of fluids at the sub-millimeter length scale. The fluid phenomena that dominate liquids at this length scale are measurably different from those that are dominant at the macroscale; for example, in terms of laminar versus turbulent flow, surface and interfacial tension and capillary forces. An advantage of the laminar flow is the possibility of fast media and temperature changes [5]. Microfluidics also have a number of other positive practical aspects like low reagent consumption $(\mathrm{nL})$, the opportunity to manipulate a large number of cells simultaneously and independently, automatic generation of a large number of different individual conditions, and easy integration of numerous analytical standard operation and large-scale integration [6]. Moreover, microfluidics provide a high degree of control over cell culture, e.g., the glucose or oxygen concentrations delivered to cells. Microfluidic cell culture devices also allow precise control of cell numbers and density in a given area or volume, their monitoring with high spatial and temporal resolution and their individual retrieval during or following experiments [7]. Besides the controllability, two other main advantages are the parallelization and the automation of microfluidic cell culture systems. Parallelization of experimental conditions allows for enhanced cell-based screening assays, with improved reproducibility as well as a reduction in reagent costs, while automation of microfluidic cell culture systems allows culturing cells for several weeks under precisely defined conditions without manual intervention. Automation of cell culture systems also leads to standardized manipulation, monitoring and sampling of cultured cells. This allows strict adherence to the timing of 
protocols, which is of particular value when dynamic processes are characterized [7]. Therefore, microfluidics has become particularly valuable for analysis of single cell dynamics.

This review discusses different techniques to design and construct a cellular array, and to analyze cells dynamically at the single-cell level. The designs of microfluidic bioreactors for living-cellular arrays are in general comparable for different cells types such as microbial and mammalian cells. We point in this review to differences that exist in adherent (mammalian) cells and non-adherent cells (microbial and mammalian cells). The most commonly used materials and methods used to build a microfluidic cell array are discussed. Furthermore, different cell arraying methods are reviewed and discussed: cell patterning on adhesive micropatterns, mechanical cell patterning as well as robotic cell printing. Finally, we compare cell array microfluidic setups and operation for single-cell types versus cell population variants. We illustrate the operation of these microfluidic bioreactors on the basis of some illustrative examples in the field of drug screening, cytotoxicity evaluation, and basic cellular and microbiology research.

\section{Construction Methods of Cellular Array Microfluidic Chips}

Miniaturization of cellular assays via cell microarrays increases assay throughput while reducing reagent consumption and the number of cells required, making these systems attractive for a wide range of assays, such as in drug discovery, toxicology, and stem cell research [8]. The most obvious way to generate cell microarrays is to miniaturize microtiter plates [1,9]. However, more complex cell arrays can be developed as well by the use of microfluidic techniques. Nowadays, microfluidic chambers can be generated in nearly any geometry in a variety of materials because of significant advances in microfabrication technologies. Even within the limited context of biological applications, microfluidic channel geometries vary from simple straight channels to complex 3-dimensional (3D) structures, and the device material varies from glass and silicon, to polymers, such as polydimethylsiloxane (PDMS) and hydrogels [6]. In the $80 \mathrm{~s}$ and 90s, microfluidic devices were mainly fabricated on silicon substrates. In the late 90s, the introduction of soft-lithography allowed for the fabrication of cheap microfluidic devices by the molding of polymers [4]. The most popular technology for the fabrication of microfluidic devices for cell biological applications is based on soft-lithography of PDMS. PDMS is an elastomer, which through simple molding procedures can be cast into microfluidic structures [10]. Its wide use as a material of choice is due to its mechanical property, which is amenable to integration of fluidic valves, essential elements for major microfluidic applications. Further, PDMS is bio-compatible and permeable to gas, which explains the strong interest of the scientific community in using this material to fabricate microfluidic devices for cell biological studies [4]. Another main advantage of PDMS is that it offers transparency and stable optical features, and the optical aberrations and auto-fluorescence induced by small volumes of cell culture medium in such devices are generally negligible. Also, the combination with fluorescent live-cell imaging is well suited. Therefore, PDMS based microfluidics provide excellent live-cell imaging conditions [7]. However, some issues are to be considered as well. PDMS has affinity for small hydrophobic molecules and thus could lead to biomolecule absorption/adsorption from the medium, thus biasing the experimental condition. The permeability of PDMS to water vapor can also lead to media drying and thus change its osmolarity [4]. 
A traditional but still widely used method of creating microfluidic systems containing structural components such as microwells or cell barriers for mechanical patterning of cells (vide infra) is to bond two layers with alignment: a substrate layer constructed with micro/nanostructures on the surface (a microstructured layer) and a channel layer with the impression of microchannels [11]. Fabrication methods are selected depending on the (bio-compatible) materials, geometries and size that are used for physical structures and channels. Various micro/nanofabrication techniques can be used for manufacturing physically modified microfluidic systems such as (Figure 1, Table 1):

1. Conventional MEMS (microelectromechanical systems) processing (photo lithography, electroplating, deposition, and etching) are used to create structures on silicium or glass substrates and soft lithography or etching is used to fabricate channels with PDMS or glass. The microstructered layer is bonded with the microchannel layer to form the microfluidic device [12-16].

2. Multilayered PDMS based microfluidic systems that are fabricated with one or multiple uses of soft lithographic process: (a) The PDMS layer with the microstructures and the channel are separately fabricated and bonded with alignment [17-20]; (b) The channel layer containing the structures is fabricated on a multilayered master mold and is bonded with a flat PDMS or glass substrate [21-23].

3. Microfluidic microchannels are fabricated with PDMS or glass by soft lithography or etching; and a photo-curable hydrogel solution fills the channel and UV light patterns or creates microstructures inside the microchannels [24-26].

4. Soft lithography techniques are used to create engraved microstructures with PDMS or UV-curable hydrogels/resins. The PDMS microchannel layer is bonded with a polymer layer to obtain a microfluidic channel with physical structures [27-30].

5. Micro/nanostructures are formed on a polymer layer or Si substrate by nanoimprinting, soft lithography or reactive etching following a suitable lithographic process. Next, a microchannel layer of PDMS or glass is bonded to form a microfluidic channel [31].
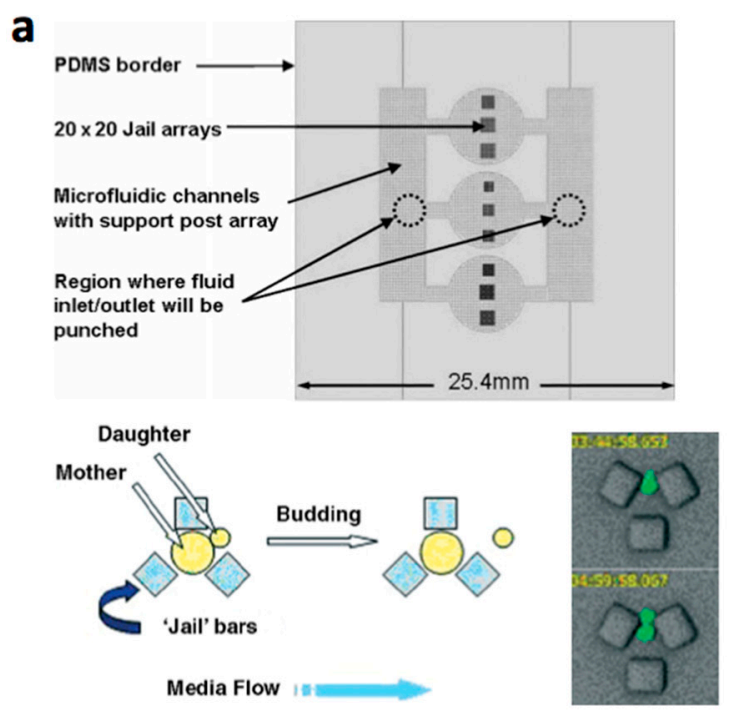

C

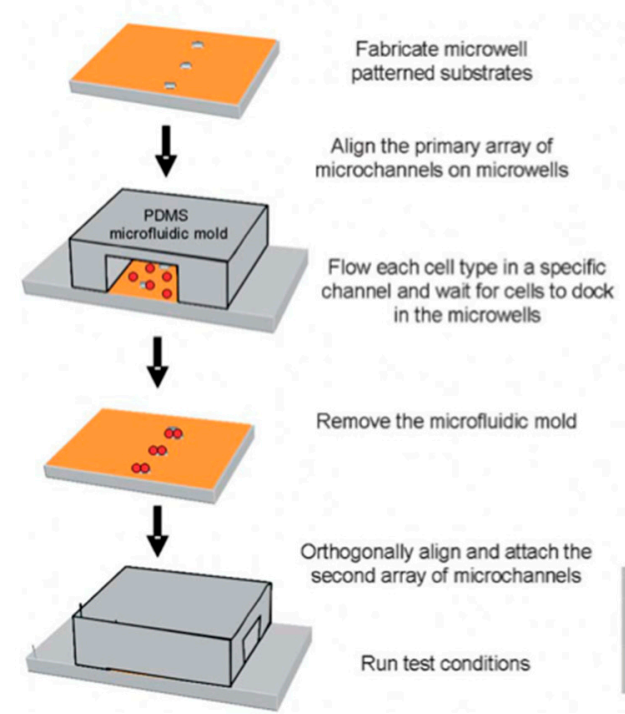

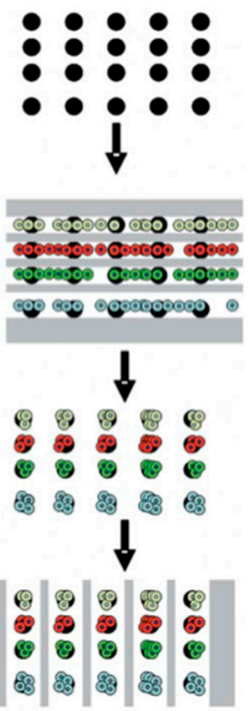

Figure 1. Cont. 
b

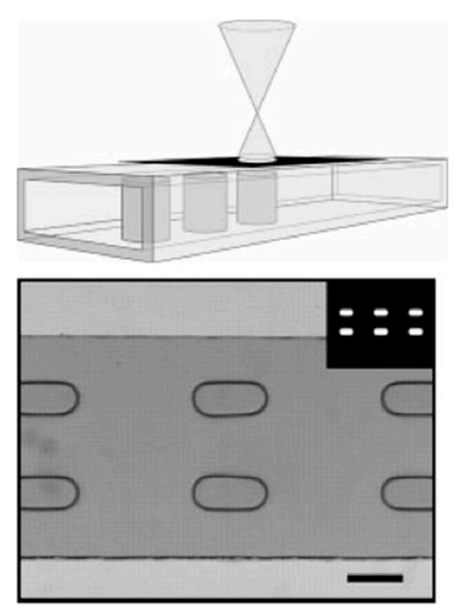

d
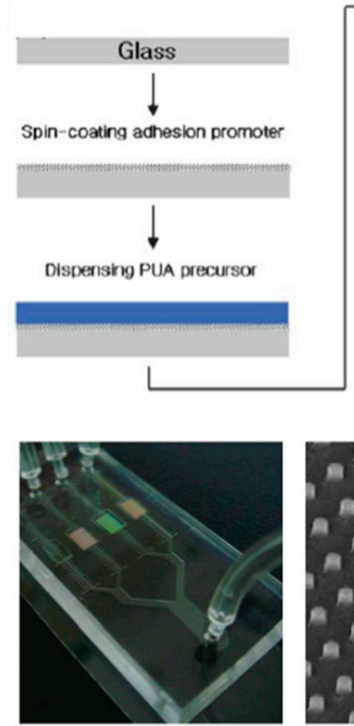
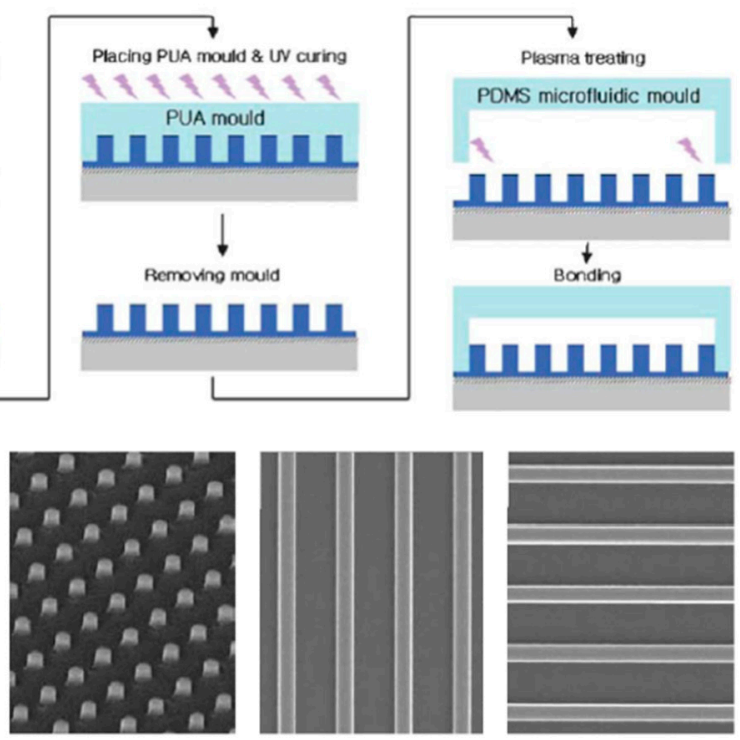

Figure 1. Examples of construction methods of microfluidic channels and structures. (a) Schematic of an individual PDMS device (size is $25.4 \times 25.4 \mathrm{~mm}$ ), and five devices were etched into a single 4 inch diameter silicon wafer (top). Individual "yeast jail" during typical asymmetric budding (bottom). Reprinted with permission from [20]; (b) Fabrication of active hydrogel components inside microchannels via direct photopatterning of a liquid phase. The simultaneous polymerization of multiple structures with a single exposure of ultraviolet light (scale bar: $500 \mu \mathrm{m}$ ). Reprinted with permission from [24]; (c) Schematic diagram of reversible sealing of microfluidic arrays onto microwell patterned substrates to fabricate multiphenotype cell arrays. Reprinted with permission from [28]; (d) A schematic diagram for the fabrication of a microfluidic channel integrated with a nanopatterned substrate [31]. Here, polyurethane acrylate (PUA) nanostructures were fabricated using UV-assisted capillary molding onto glass substrate and the patterned substrate was irreversibly bonded to the channel by treatment with oxygen plasma (top). Reprinted with permission from [31].

Table 1. Examples of materials and methods used to construct microfluidic cellular microarray chips (adapted from [11]).

\begin{tabular}{|c|c|c|c|c|c|c|}
\hline \multicolumn{2}{|c|}{ Materials } & \multicolumn{2}{|c|}{ Fabrication Methods } & \multirow[t]{2}{*}{ Array Spots } & \multirow[t]{2}{*}{ Cell Type } & \multirow[t]{2}{*}{ Refs } \\
\hline Channel & $\begin{array}{c}\text { Micro- } \\
\text { Structures }\end{array}$ & Channel & Micro-Structures & & & \\
\hline PDMS, glass & $\begin{array}{l}\text { Si, glass, } \\
\text { PDMS }^{1}\end{array}$ & $\begin{array}{l}\text { Replica } \\
\text { moulding, } \\
\text { etching }\end{array}$ & $\begin{array}{l}\text { Photo lithography, } \\
\text { deposition, etching }\end{array}$ & 1 & HL60 & [12] \\
\hline \multirow{7}{*}{ PDMS } & \multirow{7}{*}{ PDMS } & \multirow{7}{*}{$\begin{array}{l}\text { Replica } \\
\text { moulding }\end{array}$} & \multirow{7}{*}{ Replica moulding } & 1 & Jurkat, U937 & [18] \\
\hline & & & & 16 & $\mathrm{C} 2 \mathrm{C} 12$ myoblasts & [19] \\
\hline & & & & 100 & Hela & [22] \\
\hline & & & & 440 & U937, FL 60 & [23] \\
\hline & & & & 8 & HepG2 & [32] \\
\hline & & & & $100 / \mathrm{mm}^{2}$ & Hela & [33] \\
\hline & & & & 3600 & S. cerevisiae & [20] \\
\hline
\end{tabular}


Table 1. Cont.

\begin{tabular}{|c|c|c|c|c|c|c|}
\hline \multicolumn{2}{|c|}{ Materials } & \multicolumn{2}{|c|}{ Fabrication Methods } & \multirow[t]{2}{*}{ Array Spots } & \multirow[t]{2}{*}{ Cell Type } & \multirow[t]{2}{*}{ Refs } \\
\hline Channel & $\begin{array}{c}\text { Micro- } \\
\text { Structures }\end{array}$ & Channel & Micro-Structures & & & \\
\hline PDMS, glass & $\begin{array}{c}\text { Hydrogel } \\
\text { PEG }\end{array}$ & $\begin{array}{l}\text { Replica } \\
\text { moulding, } \\
\text { etching }\end{array}$ & $\begin{array}{c}\text { Photo- } \\
\text { polymerization }\end{array}$ & $>300$ & $\begin{array}{l}\text { Mouse embryonic } \\
\text { stem cells, NIH- } \\
\text { 3T3 fibroblasts }\end{array}$ & {$[24,26,27]$} \\
\hline PDMS & $\begin{array}{l}\text { PDMS, } \\
\text { hydrogel, } \\
\text { PMMA }\end{array}$ & $\begin{array}{l}\text { Replica } \\
\text { molding }\end{array}$ & Soft lithography & 25,000 & Hybridoma & [29] \\
\hline $\begin{array}{l}\text { PDMS, glass } \\
\text { Glass, } \\
\text { PDMS }\end{array}$ & $\begin{array}{l}\text { Si, hydrogel, } \\
\text { PMMA } \\
\text { PUA }^{2}\end{array}$ & $\begin{array}{l}\text { Replica } \\
\text { molding, } \\
\text { etching } \\
\text { Replica } \\
\text { molding }\end{array}$ & $\begin{array}{l}\text { Nanoimprinting, } \\
\text { soft lithography, } \\
\text { reactive ion } \\
\text { etching } \\
\text { Capillary molding }\end{array}$ & 4 & MCF10A, MCF7 & [31] \\
\hline
\end{tabular}

${ }^{1}$ PDMS: polydimethylsiloxane; ${ }^{2}$ PUA: polyurethane acrylate.

In most of the microfluidic devices, cells are growing in two-dimensions (2D) on hard plastic or glass surfaces because of the ease, convenience and high cell viability associated with this culture method. Therefore, cellular microarrays are usually 2D systems. This is especially the case for non-adherent cells, which are usually attached to the surface via linker molecules. 2D cell arrays also allow high-resolution imaging, which is the preferred method to monitor cell behavior in high throughput. For cell culture where the cellular behavior (proliferation, differentiation, metabolism) is strongly influenced by the microenvironment, 3D culture is the preferred cultivation method since the cell's microenvironment in $3 \mathrm{D}$ can mimic the characteristics of a tissue in vivo [32-35]. Cell-cell communication and differentiated cellular function are more relevant in 3D, and the impact of 3D cultures on predicting efficacy of drug treatments to actual in vivo response is great. A wide range of biomaterials can mimic several characteristics of the ECM present in 3D cell environments. 3D entrapment of cells can be performed in natural or synthetic hydrogels consisting of ECM components (e.g., collagen, laminin, Matrigel, hyaluronic acid), natural polymers such as alginate, dextran and chitosan or synthetic polymers comprising polyethylene glycol (PEG), poly(hydroxyethyl methacrylate) (polyHEMA), polyvinyl alcohol (PVA) and polycaprolactone (PCL), synthetic self-assembling peptides or artificial DNA molecules [35-47]. Natural hydrogels were gradually replaced by synthetic types due to their higher water absorption capacity, long service life, wide varieties of raw chemical resources and chemical composition controllability [48].

Cell patterning methods can be used to conduct 3D on-top or 3D cell embedded cultures [49]. To achieve the 3D on-top culture in cellular microarrays, a cell suspension is added to the ECM patterned surface, and cells are allowed to interact with that surface. Examples of on-top cultures are hepatocyte growth on a microfabricated PEG-brush surface [50], smooth muscle cells and osteoblasts on blends of poly(L-lactic acid)/poly(D, L-lactic acid) [51,52], human liver cells on collagen type I microarrays [53], epithelial cells on Matrigel microarrays [54], and mouse embryonic stem cell differentiation on a combination of five ECM molecules (collagen I, collagen III, collagen IV, laminin and fibronectin) [55]. Robotic indirect cell printing (see Section 3.3) can be used to prepare the microarrays. Direct cell 
printing of yeast cell microarrays in a microfluidic chip has been performed on an agarose-coated glass coverslip [56]. Alternatively, 3D on-top culture in cellular microarrays can be realized by mechanical patterning in microwells (see Section 3.2) composed of hydrogels, e.g., agarose microwells [57]. More complex fabrication methods can be used for the direct and simultaneous fabrication of sub-micron topographical and chemical patterns on a hydrogel. For example, localized e-beam microlithography was used to construct topographical and chemical cues for the guided growth of neural cell networks on polyamidoamine hydrogels [58].

$3 \mathrm{D}$ cell-embedded cultures are prepared by mixing cells with a gel of interest (e.g., alginate, collagen, Matrigel), and depositing the hydrogel-cell mixture on surfaces by robotic direct cell printing. Commonly used hydrogel materials for bioprinting are PEG, collagen, hyaluronic acid, gelatin, fibrin, polycaprolactone and alginate [59]. Since some cell printers (i.e., ink jet printer) are limited to dispensing low viscosity solutions and mixing by pipetting is required to prepare the hydrogel-cell solution, ionic hydrogels (such as alginate) can be used [60-62]. In this case, the hydrogel-cell solution is spotted on $\mathrm{Ca}^{2+}$ or $\mathrm{Ba}^{2+}$ surfaces, which cross-links the alginate polymers on the surface.

\section{Cell Arraying Methods}

\subsection{Cell Patterning on Adhesive Micropatterns}

A variety of different patterning techniques have been developed to present adhesive ligands at a range of scales to investigate biological events, pushing the envelope on the minimum feature down to the nanometer scale [63-68]. Although micropatterning approaches have been developed for multiple cells (microsheets and confluent sheets), we review here popular micropatterning techniques for single-cell adhesion, which require micropatterns at the subcellular to single-cell resolution of around 5-40 $\mu \mathrm{m}$.

Microcontact printing has become the most popular and widely used technique [69] (Figure 2a). A PDMS stamp with desired microfeatures is used to print adhesive biomolecules onto the culture substrate [70,71]. The PDMS stamp is fabricated by using photo lithography or soft lithography, and micropatterns with a resolution of 1-2 $\mu \mathrm{m}$ can be created [72]. Various "inks" have been used to generate patterns of differential adhesiveness on culture surfaces, and the choice depends on the experimental requirements [73]. For mammalian cells, organic inks include ECM proteins (such as fibronectin, collagen, vitronectin and laminin) or integrin-binding peptides [74-76], such as RGD (Arg-Gly-Asp), a peptide representing a cell adhesion-mediated sequence within fibronectin [75]. Various other chemistries permit mammalian cell attachment but the use of ECM proteins is unrivalled in its ability to actively encourage cell attachment [76]. The patterns are "backfilled" with a cell repellent molecule. Polyethyleneglycol (PEG) is one of the most effective and commonly used non-fouling molecules [77].

Living Escherichia coli could also be direct microcontact printed on agarose substrates with cellular resolution [78]. Despite its popularity, microcontact printing has several drawbacks for cell biology labs, such as the requirement of an initial etching step to microfabricate the stamp and variations in the quality of the protein transfer [71].

Another soft lithography technique to pattern cells is microfluidic patterning where PDMS microchannels are used to flow and deposit protein solution in the form of a desired pattern $[73,79,80]$. The channels 
are removed before cell seeding. Choosing different solutions for distinct channels can create multi-component surfaces, and the cells can be deposited along with the solution.

Adhesive micropatterns can also be constructed using photopatterning [81]. Protein grafting on PEG surfaces can be induced by photosensitizers [82]. Alternatively, photobleaching of fluorophores by laser excitation induces protein adsorption [83-85]. UV light can also be used to detach the protein-repellant part of a molecule that has been grafted on the substrate to allow further binding of ligands $[72,86,87]$ (Figure 2d). Spatially controlled UV exposure can be obtained with a photomask in contact with the substrate [88,89], by placing the photomask in the object plane of the microscope objective [84], or using a liquid crystal display [90].

Laser-patterning strategies, which avoid the fabrication of a costly mask, have been developed (Figure 2b). A thin PVA film can be ablated by raster scanning a focused laser [91]. Laser scanning lithography can be used for the fabrication of multifaceted, patterned surfaces and for image-guided patterning $[92,93]$. This photothermal-based patterning technique allows for selective removal of desired regions of an alkanethiol self-assembled monolayer on a metal film through raster scanning a focused $532 \mathrm{~nm}$ laser using a commercially available laser scanning confocal microscope.

Dip-pen nanolithography (DPN) and polymer pen lithography (PPL) are recently developed maskless techniques to microfabricate cell adhesive micropatterns (Figure 2c). In DPN, the tip of an atomic force microscope (AFM) cantilever acts as a "pen", which is coated with a chemical "ink", and put in contact with a substrate in a controlled manner and nanometer precision in order to write desired surface patterns with the ink [94]. Due to the general mild process conditions, DPN enables direct nanoscale deposition of delicate materials as e.g., ECM proteins onto a substrate in a flexible manner [95]. PLL is another related method that is suitable for deposition of larger (yet still small, i.e., femtoliter range) volumes of ink is the use of microchannel cantilevers for small volume spotting [96]. Like DPN, this method utilizes the precise spatial control of an AFM setup to enable highly localized delivery of functional materials onto surfaces and predefined structures. These methods can be used for high-precision localization, such as on fragile sensor-prestructures [97] and nano-optical devices [98]. For large area patterning with microscale arrays on flat surfaces, PPL can be used [99]. This technique, as a hybrid of DPN and microcontact printing $(\mu \mathrm{CP})$ has also been demonstrated to be feasible for the production of large area, multiplexed micropatterns with bioactive functions, e.g., protein patterns for cell adhesion and neural guidance [100].

Other micro-nanopatterning techniques include nanoimprint lithography [67,101,102], electron beam lithography [103-106], nanosphere lithography [107-109], and polymer demixing [110]. 
a

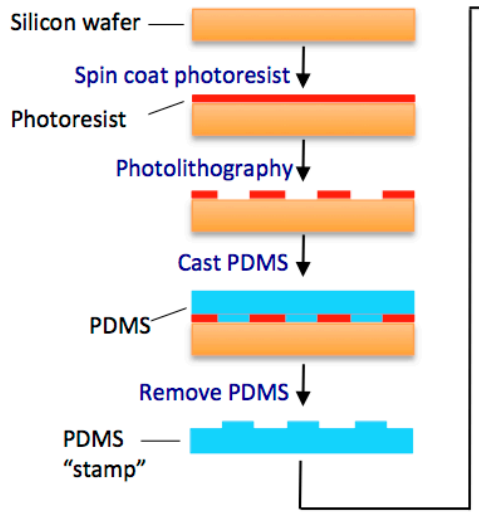

b

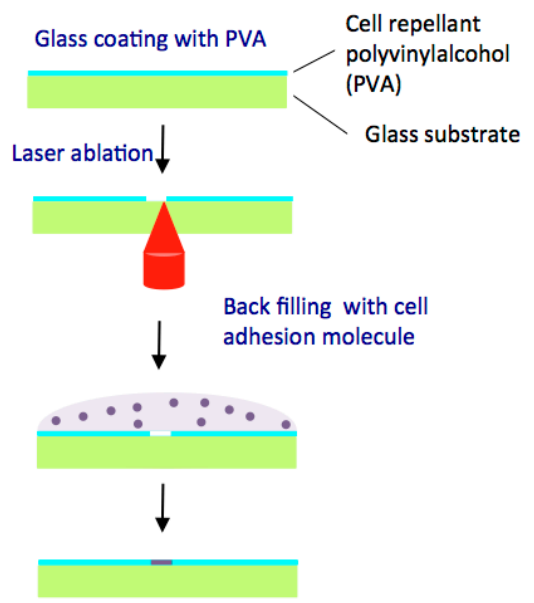

C

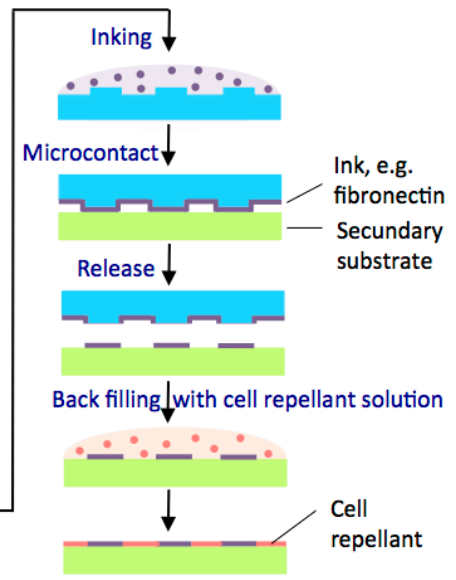

d

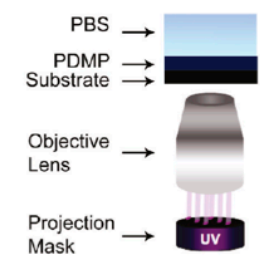

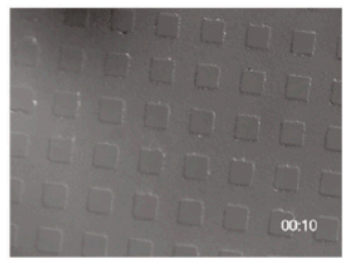

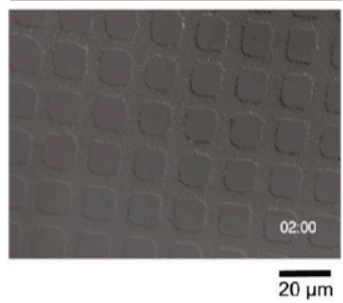

Figure 2. Examples of cell patterning on adhesive micropatterns. (a) Schematic representation of the microcontact printing ( $\mu \mathrm{CP}$ ); (b) Schematic outlining of the fabrication of cell adhesion micropatterns by using laser patterning; (c) Schematic of multi-ink polymer pens with four different inks (top) and lithography (middle left). Using the differently inked areas of the pen array at the same surface position can generate multiplexed patterns. Multiplexed micrometer patterns on the $\mathrm{cm}^{2}$ scale find applications in cell biology for example (middle right). Scheme of the writing process for a three-ink pattern (bottom). Reprinted with permission from [100]; (d) Schematic of microscope projection lithography (left). DIC images of PDMP film with various UV exposure times (right). Reprinted with permission from [87]. Copyright 2010 American Chemical Society. 


\subsection{Mechanical Cell Patterning}

Microwells: Microfabricated cell arrays are often directly created as mechanical barriers to capture cells [3] (Figure 3). Various microfabrication techniques have been used to fabricate microwell substrates for cell cultivation (Table 2). The microwell can have a diameter of several hundred micrometers up to the dimensions of a single cell. Single-cell microwell arrays allow large numbers of cells to be stimulated in a massively parallel fashion [111]. Various substrates such as hydrogels, silicon, photoresist, PDMS or glass, and combinations, such as for example a glass bottom and PDMS walls of the well, have been used as microwell materials (Table 2).

Microchambers: Cells can be trapped in culture chambers by using inlet and outlet valves. Multilayer soft lithography is applied for the large-scale integration of microfluidic valves and has been broadly applied to studies on bacteria [112-114], yeast [114,115] and mammalian cells [116-119]. Culture chambers can also be open on both sides [120,121] and one side [122]. In this case, the dimensions of the channel that fits single-cell dimensions confine the cells. These culture chambers are suitable for non-adherent cells such as bacteria [123]. Cells can also be trapped by gravity in larger chambers, where the cells are trapped at the bottom of the chamber, which is at a depth where shear stress is negligible $[119,124]$. In this case, the culture chambers are designed with an inverted geometry with flow channels running over the top of the chambers.

Mechanical cell trap barriers: Mechanical barriers have also been used to capture cells from suspensions in fluidic devices $[3,125,126]$. Fluid flow pushes the cells into the traps. Therefore, these cell traps are also designated as hydrodynamic cell traps [127]. Barriers have been designed with a small fluidic leak that allowed trapping single cells [16,20,128,129]. This cell-trapping concept has been extended towards the trapping of two different cells into one trap, which allowed single-cell analysis of cell fusion by the paired couples [130].
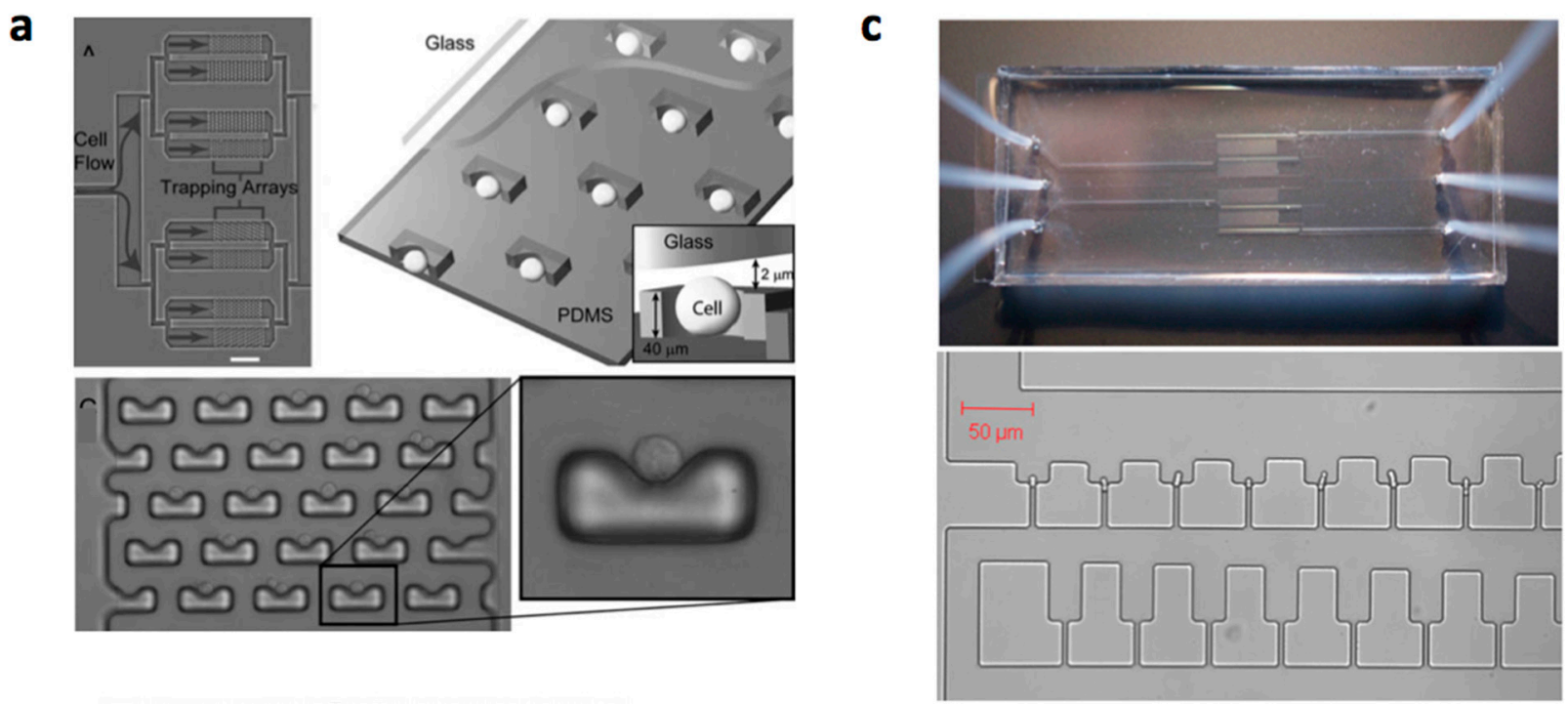

Figure 3. Cont. 
b

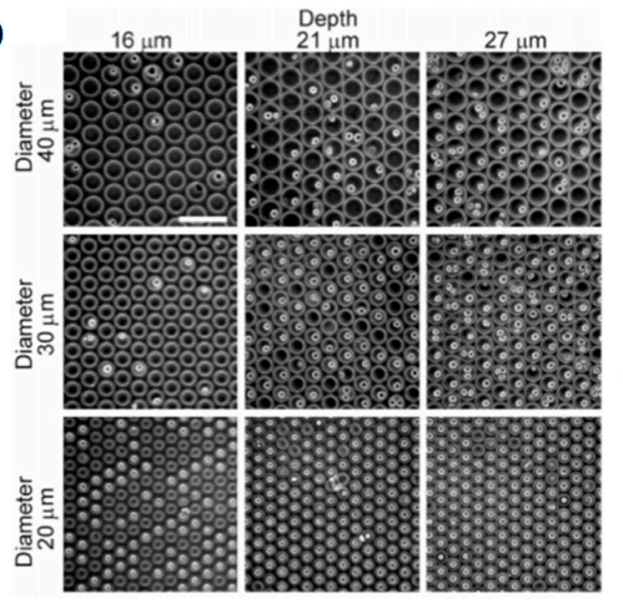

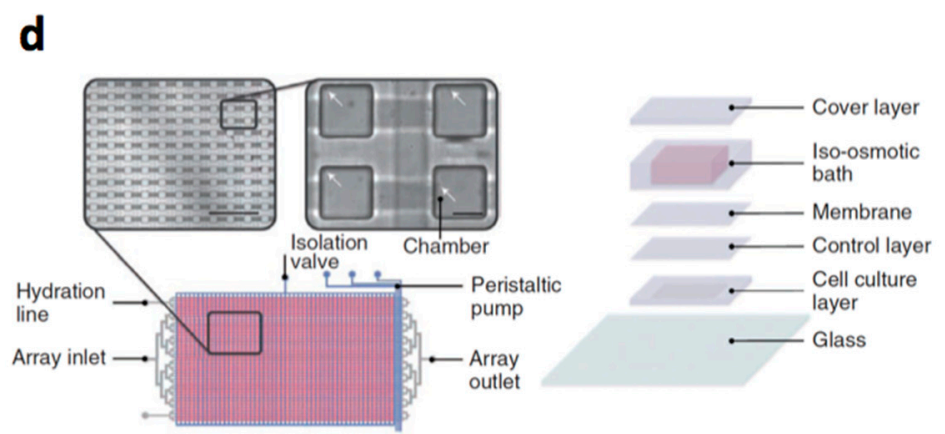

Figure 3. Examples of mechanical cell patterning. (a) Single cell trapping arrays. A photograph of the cell-trapping device is shown demonstrating the branching architecture and trapping chambers with arrays of traps (top). The scale bar is $500 \mu \mathrm{m}$. Reprinted with permission from [129]; (b) Nine representative pictures of RBL-1 cells in microwells for all the combinations of three different diameters (range diameter is $20-40 \mu \mathrm{m}$ ) and three different depths (range height is 16-27 $\mu \mathrm{m}$ ) [111]. Reprinted with permission from [111]. Copyright 2010 American Chemical Society; (c) Image of the fabricated device showing external fluidic interconnects [120] (top). Confocal microscope image of single Schizosaccharomyces pombe cells held separately in the first row of a trapping region (bottom); (d) Iso-osmotic perfusion microfluidic cell culture array. Schematic of the device with micrographs as insets. The cell culture layer contains 1600 chambers connected by flow channels. Arrows point at single cells (left). Schematic of the layers that are assembled during device fabrication (right). Reprinted with permission from [119].

Table 2. Examples of microwell substrates.

\begin{tabular}{|c|c|c|c|c|}
\hline Material & Diameter/Width & Cell Type & Characteristics & Refs \\
\hline \multirow[t]{2}{*}{ PDMS } & $20-40 \mu \mathrm{m}$ & NIH3T3 ${ }^{1}, \mathrm{RBL}_{-1}{ }^{2}$ & Single-cell screening & {$[111]$} \\
\hline & $25 \mu \mathrm{m}$ & Hepatocyte & Single cell oxidative stress screening & {$[131]$} \\
\hline \multirow[t]{2}{*}{ Photoresist $1002 \mathrm{~F}$} & $50 \mu \mathrm{m}$ & $\mathrm{HeLa}$ & Viability assessment & {$[132]$} \\
\hline & $50 \mu \mathrm{m}$ & $\mathrm{H} 1299, \mathrm{MEF}^{3}$ & RhoA GTPase biosensor & {$[133]$} \\
\hline Poly(ethylene glycol) & $40-150 \mu \mathrm{m}$ & $\begin{array}{l}\text { Murine embryonic } \\
\text { stem cells }\end{array}$ & $\begin{array}{l}\text { The formation of homogeneous } \\
\text { embryoid bodies }\end{array}$ & {$[134]$} \\
\hline Polystyrene & $10 \mu \mathrm{m}$ & B-cells & Detecting activated cells & [135] \\
\hline $\begin{array}{l}\text { Optical imaging } \\
\text { fibers }\end{array}$ & $7 \mu \mathrm{m}$ & $\begin{array}{l}\text { NIH } 3 \text { T3 mouse } \\
\text { fibroblast cells }\end{array}$ & Observation of cell fluorescence & {$[136]$} \\
\hline Etched glass & $20 \mu \mathrm{m}$ & Non-adherent cell lines & Individual cell based assays & {$[137]$} \\
\hline SU-8 on coverslip & $90 \mu \mathrm{m}^{2}$ squares & Adult neural stem cell & $\begin{array}{l}\text { Culturing and dynamic monitoring of } \\
\text { stem cell proliferation }\end{array}$ & {$[138]$} \\
\hline \multirow[t]{2}{*}{ PDMS } & $25-50 \mu \mathrm{m}$ & $\mathrm{BCE}^{4}$ & PDMS wells coated with fibronectin & [139] \\
\hline & $160 \mu \mathrm{m}$ & $\mathrm{HSC}^{5}$ & $\begin{array}{l}\text { HSC proliferation control at the } \\
\text { single-cell level }\end{array}$ & {$[119]$} \\
\hline
\end{tabular}


Table 2. Cont.

\begin{tabular}{ccccc}
\hline Material & Diameter/Width & Cell Type & Characteristics & Refs \\
\hline $\begin{array}{c}\text { Poly(ethylene glycol) } \\
\text { diacrylate }\end{array}$ & $70 \mu \mathrm{m}$ & HeLa & $\begin{array}{c}\text { Single cell analysis } \\
\text { Wiping technique to localize cells in } \\
\text { microwells }\end{array}$ & {$[140]$} \\
\hline $\begin{array}{l}{ }^{1} \text { NIH3T3: NIH3T3 fibroblast; }{ }^{2} \text { RBL-1: rat basophilic leukemia; }{ }^{3} \text { MEF: mouse embryonic fibroblast; }{ }^{4} \text { BCE: } \\
\text { bovine adrenal capillary endothelial cells; HSC: }{ }^{5} \text { hemapoietic stem cells; }\end{array}{ }^{6}$ ES: embryonic stem cells.
\end{tabular}

\subsection{Robotic Cell Printing}

In the initially developed cell microarrays, microbial cells were printed on an agar growth medium using robotic fluid-dispensing devices and could grow as microcolonies, or cells were grown in multiwell plates and printed on a glass slide for imaging, or only short-time analyses on living cells were performed. High-throughput experiments on a library of cells require on-chip cell culture. Microchip 2- or 3D cell cultivation techniques can provide many advantages for cell culture systems because the scale of the cultivated environment inside the microchip is fitted to the size of the cells. Cells can be directly printed on surfaces (direct cell printing) or attached to printed adhesive biomolecules (indirect cell printing) (vide supra).

Direct cell printing: To create cellular microarrays, cells can be spotted or "printed" using a fluid-dispensing device ("cell printer"). It is essential to obtain a highly reproducible number of living cells per spot and an optimised printing process that is qualified for reproducible production of microarrays with cells that keep their vitality and function for analysis. Spot formation techniques are categorised as "contact printing" and "non-contact" printing $[142,143]$. To produce cellular arrays, more often non-contact-based devices are used, such as modified inject printers or piezo-driven tips [144-149], although in some publications contact-based arrayers have been used [118,150-152]. In non-contact printing techniques, the liquid metering is not determined by the complex interplay of the pin, the liquid and substrate, but is separated from the substrate, because no contact between the printing tool and the substrate occurs. The fluid is ejected as a flying droplet or jet towards the surface from a certain distance, which makes metering more precise. One concept of non-contact printing is based on syringe-solenoid-driven printers, where a reservoir and a high-speed microsolenoid valve are connected to a high-resolution syringe (e.g., the synQUAD system, Genomic Solutions). Further non-contact microarrayers are piezoelectrically driven, where a technology similar to the one used in ink-jet printer is used (e.g., MicroDrop, PerkinElmer, Scienion, GeSim, M2-Automation). A piezo-actuator is fixed at the top of the dispenser tip. The squeezing of the tip forced by the piezo-actuation induces droplet ejection out of the capillary. The fast response time of the piezoelectric crystal permits fast dispensing rates ( $\mathrm{kHz}$ range), and the small deflection of the crystal generates droplets from hundreds of picoliters to a few nanoliters.

Another method is laser-induced bioprinting where photons from a laser beam trap and guide cells by exploiting the differences in refractive indices of cells and cell media [149,153-155]. Near-infrared wavelengths (700-1000 nm) have been used to avoid exposure to excessive thermal energy [154]. Alternatively, laser-induced bioprinting methods have been developed where cells are encapsulated in a hydrogel film, which is propelled forward as a jet by the pressure of a laser-induced vapour 
bubble [156-161]. The heat transfer from the laser pulse to the cell-encapsulating donor film leads to the transfer of material from the donor film to the receiving substrate [155]. Patterning is performed on the receiving substrate that is usually fixed on a computerized stage and coated with a cell culture medium or a biopolymer layer for cellular adhesion.

Cells can also be patterned using a picoliter based cell encapsulation technology via acoustics [162-164]. Acoustic droplet ejection uses acoustic radiation force associated with an ultrasound field to transfer momentum into the ejection of a liquid droplet from an air-liquid interface [165,166]. Advantages of this technology over other printing approaches are [155]: no nozzle is required for droplet generation since droplets are created from an open liquid reservoir, acoustic waves do not harm cells due to low power droplets generation with only a few microseconds of pulse duration, acoustic ejectors can be combined in an adjustable array format as multiple ejectors. "Acoustic tweezers" that utilized standing surface acoustic waves, have also been used to manipulate and pattern cells [167] in a microfluidic chip [168]. Another technique to generate cell-encapsulating hydrogel droplets is the valve-based droplet ejection method where the droplets are ejected onto a surface $[169,170]$. The size and number of cells in a droplet and the amount of droplets are controlled by the valve opening duration and actuation frequency [171].

The choice of cell substrate material is critical for achieving cell attachment in 2D microfluidic perfusion culture systems. Tissue culture polystyrene is difficult to use because it cannot bond PDMS, cannot be autoclaved, is autofluorescent in the UV/blue range $(360 / 460 \mathrm{~nm})$, and is poorly compatible with microfabrication of the substrate. Therefore, other materials are commonly used as the cell substrate: glass [138,172,173], PDMS [174], poly(methylmethacrylate) (PMMA) [175], silicon [176], and silicon nitride [177]. The construction of chemically modified solid supports is of particular importance in cell-based microarrays [76]. Cell attachment on cell substrate material can be promoted via adhesive proteins or peptides adsorbed from the cell culture media or via pre-immobilised cell-attachment proteins such as gelatin [178], collagen [179], laminin [176,180], fibronectin and vitronectin (or the immobilisation of integrin-binding peptides such as RGD (Arg-Gly-Asp) [181], or poly-L-lysine [180] (vide supra). Microbial cells can be attached to a glass substrate by linker molecules such as poly-L-lysine or glutaraldehyde [182-184]. For yeast cell adhesion, the mannan-binding lectin concanavilin A can also be used [185,186]. With PDMS microfluidic perfusion culture systems, glass is often used as the cell culture substrate because glass can be permanently bonded to PDMS [178].

Indirect cell printing: Complex cellular micropatterns have been created using the inkjet printing of an albumin cross-linking polyethleneimine (PEI) solution on a substrate [187]. Treatment with a cationic polymer makes the albumin patches cell adhesive and subsequently cells were seeded on the patches. Cells have been patterned mediated by DNA hybridization to form cellular microarrays [188]. Therefore, cell bearing single-stranded DNA sequence on their surface bound to a complementary spot on a $60 \mu \mathrm{m}$-printed DNA microarray.

\subsection{Selection of Cell Arraying Method}

Cell arraying techniques have been developed for microbial and mammalian cells. Mammalian cells can be adherent or non-adherent. Cell arraying methods of non-adherent mammalian cells are comparable with microbial cell arraying methods. The advantages and limitations of cell patterning on adhesive micropatterns, mechanical cell patterning and robotic cell printing are compared in Table 3. 
Table 3. Advantages and limitations of the different cell arraying methods.

\begin{tabular}{|c|c|c|}
\hline Method & Advantages & Limitations \\
\hline Adhesive micropatterns & $\begin{array}{l}\text { - Simple and versatile } \\
\text { - Deposition of bioactive and/or non-fouling cell } \\
\text { repellant compounds for spatially controlled cell } \\
\text { attachment } \\
\text { - Micrometer-resolution pattern formation } \\
\text { - Micropattern shape is adaptable } \\
\text { - Single cell micropatterns to control the cell } \\
\text { morphology } \\
\text { - Cell-cell communications }\end{array}$ & $\begin{array}{l}\text { - Deposition of micropatterns limited } \\
\text { to flat substrata } \\
\text { - Limited number of molecules and } \\
\text { substrata can be used } \\
\text { - Requires microfabrication capability }\end{array}$ \\
\hline $\begin{array}{l}\text { Mechanical cell patterning } \\
\text { Microwells } \\
\text { Microchambers } \\
\text { Mechanical cell trap } \\
\text { barriers }\end{array}$ & $\begin{array}{l}\text { - Sub-micrometer resolution } \\
\text { - Trapping and analysis is possible } \\
\text { - Accessible for cell-cell communication studies } \\
\text { - Hydrodynamic trapping allows convective } \\
\text { control of the cell's microenvironment } \\
\text { - 3D cell culture possible }\end{array}$ & $\begin{array}{l}\text { - Requires extensive (complex) } \\
\text { laboratory procedures } \\
\text { - Clean room availability preferred }\end{array}$ \\
\hline $\begin{array}{l}\text { Robotic printing } \\
\text { Indirect cell printing } \\
\text { Direct cell printing }\end{array}$ & $\begin{array}{l}\text { - Simple patterning method } \\
\text { - Micrometer resolution } \\
\text { - Spotting of cells or biomolecules at defined } \\
\text { positions (high-resolution non-contact printers can } \\
\text { print into microwells) } \\
\text { - 3D cell culture possible }\end{array}$ & $\begin{array}{l}\text { - Micropattern shape is not adaptable; } \\
\text { only circular spots } \\
\text { - Only a few methods can achieve } \\
\text { single-cell resolution } \\
\text { - Printers are not cheap } \\
\text { - Sensitive cells (mammalian cells) } \\
\text { can suffer from the high shear stress } \\
\text { during direct cell printing } \\
\text { - Limited number of biomaterials can } \\
\text { be used }\end{array}$ \\
\hline
\end{tabular}

For adherent mammalian cells (the vast majority of mammalian cells), cell patterning on adhesive micropatterns is the method of choice as a number of advantages and applications are involved. Micropatterning techniques have been used to control cell-substrate interactions by micropatterning specific ECM (extracellular matrix) proteins and by producing functional model tissues in a 2D or a 3D context [189]. Cell growth on well-defined, single-cell geometrical ECM protein micropatterns has several advantages since they overcome the artificial uncontrolled culture conditions of a conventional growth on a flat substrate (such as a Petri dish or multiwell plate) where the reproducibility of their architecture is completely lost due to the lack of spatial information. Therefore, single-cell growth on micropatterns improves the visualization and quantitative analysis significantly [190], since the adhered cells precisely adapt their cytoskeleton architecture to the geometry of their environment [81]. This allows cell normalization and detects subtle changes in cell response to perturbations [191]. In addition to geometric control over cell shape, micropatterning methods have been used to investigate cell-cell interactions [192]. These microfabrication approaches enable a quantitative investigation into the extent of homo- and heterotypic interactions. Micropatterning technology has been used to overcome problems associated with conventional cell-cell interaction methods [81]. Precise control of the cell-cell interactions at the single-cell level has been demonstrated for cells grown on micropattern networks [193]. Moreover, 
the growth of model cell cultures on adhesive micropatterns could prove useful in the early phases of drug discovery. A current problem in the pharmaceutical industry is that cells cultured in vitro often respond differently to potential therapies than cells do in vivo, leading to failure of promising drug candidates once they are put through clinical trials [194]. Controlling the ECM pattern, and thus standardizing the individual cells, can lead to more predictive responses.

Cell patterning on adhesive micropatterns has several advantages such as it is a simple and versatile method, spatially controlled cell attachment is achieved with micrometer resolution, and adhesion of cells to various shapes of single-cell adhesive patterns (Table 3). Major limitations are that the deposition of micropatterns is limited to flat substrata, a limited number of molecules and substrata can be used, and microfabrication capability is required.

Mechanical cell patterning in microwells, microchambers or mechanical cell trap barriers can be achieved at single-cell resolution, cell-cell communication can be studied at the single-cell level, 3D cell culture is possible, and hydrodynamic cell trapping allows fast convective control of the microenvironment of a single cell (Table 3). Limitations are that extensive laboratory procedures, which can be rather complex (i.e., for the construction of mechanical cell trap barriers), are required. Clean room access, which is usually not in the reach of a cell biology laboratory, is preferred.

The choice of bioprinting technique depends on evaluating performance based on throughput, droplet size, spatial resolution, single-cell control, apparatus cost, cell viability, and choice of biomaterials (such as hydrogel type of 3D constructs). The minimal droplet volume can range between femto- to nanoliter droplets, resulting in spot sizes between 10 and $500 \mu \mathrm{m}$ [155,195]. Bioprinting has proven to provide repeatable cell or biomaterial arrays with high temporal, spatial control and versatility (Table 3). Direct cell printing of 3D cell arrays is achievable. Cell printing can be used to print inside microfluidic channels and microwells, where each microwell is individually addressable. Limitations are that the micropattern shape is limited to a disk shape, expensive equipment is needed, cells can suffer from the exerted shear stress (method dependent) during printing, and a limited number of biomaterials for printing can be used.

\section{Operation and Applications of Microfluidic Cell Microarrays}

\subsection{Microfluidic Operation}

Microfluidic systems generally consist of a set of fluidic operation units: a method of introducing reagents and samples, methods for moving these fluids around on the chip, and for combining and mixing them, and measurement devices, such as microscopic imaging [196]. Simple control systems such as syringe pumps or pressure regulators, allow to control when and how fast individual fluid streams flow. However, in addition to inducing a constant flow in microchannels, more complex applications require systematic control of both spatial and temporal parameters of flow within a device. One fundamental mechanism to reroute a fluid on a chip is to physically alter the channel networks with the use of valves. Multilayer soft lithography is used to create valves and pumps [21,197]. The material of choice is PDMS due to its elasticity. Microfluidic multiplexing technology leads to the fabrication of devices with thousands of micromechanical valves and hundreds of individually addressable reaction chambers. A key component of these networks are the fluidic multiplexor, which is a combinatorial array of binary 
valve patterns that exponentially increases the processing power of a network with a minimal number of inputs $[198,199]$. However, these microfluidic large-scale integration systems are complex and require expensive off-chip devices. Additionally, the number of individual addressable culture microchambers is limited due to the limitations in interfacing capabilities.

Besides the active microfluidic control systems, devices that use a passive mean of control have been developed. Examples are chemically driven flow directions [24] or microscopic fluidic control by the use of an aqueous viscoelastic polymer solution as a working fluid [200]. These methods suffer from the limitations that particular solutions are required. Another approach based on the use of passive surface tension pumping has been developed [201]. This technique requires the deposition of precise amounts of fluids on each inlet and outlet and the method is also vulnerable to many environmental factors such as humidity and temperature.

Robotic cell printing techniques have been developed that allow cell patterning in a fluidic channel on a flat substrate or in microwells [56,202,203]. Some printing techniques allow addressing individual spots or microwells. With micrometer resolution, spot diameters of 10-100 $\mu \mathrm{m}$ (vide supra) are reachable, resulting in up to $10^{5}$ spots/array.

\subsection{Single-Cell Measurement/Monitoring in Microfluidic Devices}

A fundamental goal of cell biology is identifying how cell behavior arises from the dynamic collection of environmental stimuli to which the cell is exposed [204]. From a biosystems science and engineering perspective, there is great interest in how the cell behaves as a system that processes time-dependent input signals into output behavior(s). Ideally, with knowledge of the history of the ensemble of environmental stimuli, one would be able to predict the precise behavior that a particular cell would exhibit under a given stimulus. Unfortunately, cells under seemingly identical environmental conditions often display a distribution of heterogeneous behavior(s) [128,205-214]. This appears to be partly due to probabilistic behavior in the "decision" processes that connect input and output [205,215-217]. Underlying the links between inputs and outputs are systems of interconnected molecular interactions (signalling pathways). Signalling within one pathway as well as cross-signalling between pathways, localization of reactions and the sometimes small number of molecules involved in signalling, contribute to stochastic behavior in these systems [205,215,218,219]. Because of the meanwhile well-documented heterogeneity within cell population, increased emphasis has been put on analysing a large number of single cells and determining distributions of responses [128,209,217]. New tools, based on microfabrication and microfluidic technologies, are now allowing improved dynamic control of environmental variables for high-throughput single cell analysis [220-225]. These experimental technologies combined with systems analysis of signalling pathways are expected to lead to an improved quantitative description of single cell function [204].

Several single-cell analysis techniques have been developed, which may be classified in terms of information content (number of elements capable of being studied simultaneously) and throughput (number of cells studied in a given time). The simplest and most widely used forms of single-cell analysis are fluorescence microscopy and flow cytometry. Automated microscopy techniques, often termed high-content screening (HCS) or "cellomics", recently provided also quantitative insight into cellular behavior and in most cases are applied to observe the response of the cells. The utility of single-cell 
measurements with high temporal resolution has been initially demonstrated by bacterial studies, which used optical microscopy to observe Escherichia coli over long time periods and reveal interesting temporal fluctuations and cell-to-cell variability that would otherwise be masked by population-wide measurements [216,226]. A microfluidic microchemostat has been constructed and used to acquire single-cell fluorescence data from $S$. cerevisiae over many cellular generations [125,202,227-229]. One way in which cells can rapidly respond to environmental stimuli is to alter the localization and abundance of proteins [230,231]. In a microfluidic device, these aspects can be studied on live-cell microarrays under various growth conditions or in response to environmental insults.

Cellular imaging is emerging as a crucial tool (see Tables 4 and 5) that enables the integration of complex biology, and addresses both high-content and high-throughput needs [232,233]. Important features of HCS systems are [234]: analysis on the level of single cells, subpopulation analysis, analysis on the subcellular level, acquisition and/or analysis of multiple parameters, data with temporal resolution, data qualities can be related to one another, decreased rate of false-positives or false-negatives, increased physiological relevance, increased sensitivity, and extended possibilities to perform post-screen data mining. High-throughput methods for describing cell phenotypes such as transcriptional and proteomic profiling allow broad, quantitative, and machine-readable measures of the responses of cell populations to perturbations. Automated microscopy has the potential to complement these profiling approaches by allowing fast and cheap collection of data describing protein behaviors and biological pathways within individual cells [202,235-237]. High content, image-based cell assays are rapidly emerging as valuable tools for the pharmaceutical industry and academic laboratories for use in both drug discovery and basic cell biology research [238,239]. Compared with biochemical assays, they probe a chemical's activity on a cellular phenotype rather than simply testing for binding to a particular isolated protein that may be, in the end, less physiologically relevant [240]. Image-based assays also compare favorably to other types of cell-based assays (e.g., reporter assays using plate readers) because multiple features of the cell's status and health can be observed, including very general phenotypes, such as overall cell health, and very specific phenotypes, such as localization of a particular phosphorylated form of a signalling protein or a fluorescent protein tagged transcription factor.

The combination of time-lapse microscopy, quantitative image analysis and fluorescent protein reporters has enabled observation of multiple cellular components over time in individual cells [241] and has been applied to e.g., drug discovery, cytotoxicity evaluation, cell biology and microbiology research (Tables 4 and 5). In conjunction with mathematical modelling, these techniques can also provide powerful insights into genetic behavior in diverse microbial systems. For example, a quantitative system-wide analysis of mRNA and protein expression in individual cells with single-molecule sensitivity using a yellow fluorescent protein fusion library for E. coli was carried out [242]. To this end, a PDMS microfluidic chip was used for imaging 96 library strains at once.

\subsection{Microfluidic Cell Array Culture Applications}

The significant advances in the microfabrication technology that are described in the first part of this review allow for highly adapted microfluidic systems with opportunities for high-throughput and multiplex analyses. Cell microarrays provide an attractive solution because they can hold at least several thousand spots on one slide, which enables e.g., a genome/proteome-wide screen on only one slide for 
microbial cells and on a few slides for human cells [1]. Many microfluidic studies describe methods that aim to replace traditional macroscale assays [5]. Also, various surface chemistries have been adapted to create cell-friendly surfaces, enabling the study of either short-term (seconds/minutes) or long-term (hours/days) cellular behaviors. As such, microfluidics has been intensively employed in various fields of chemical, (micro)biological, pharmaceutical, and medical studies in recent years [6]. High-throughput single-cell measurements of cellular responses are of great importance for a variety of applications including drug screening, toxicology, basic cell biology and microbiology research (Tables 4 and 5).

Dependent on the scope of the cell assay, microfluidic cell microarray devices can be designed to obtain a high throughput (a) by the parallel screening of multiple samples (e.g., concentrations of disturbing chemical compound) for one target (one cell type); (b) by the simultaneous screening of one sample for multiple targets (various cell types) (multiplexing); or (c) by a combination of both [243]. Examples of microfluidic cell microarrays where the behavior of 1 cell type is assessed (case (a)) are compared in Table 4, and where the behavior of multiple cell types is studied, are tabulated in Table 5. In each table, examples are subdivided in devices for adherent and non-adherent cells.

Drug discovery applications. A primary goal for much of the microfluidics community is to develop technologies that enhance investigations in medical research and drug discovery [244-249]. Cellular microarrays hold great potential in screening drug candidates for efficacy and toxicity at high throughput, especially compared to the commonly used animal models because of the significant reduction of the costs and the less labor-intensive process $[8,250]$. Therefore, cell-based assays have become an integral part of drug screening the pharmaceutical industry. These assays are extremely useful to evaluate potential drug targets by functionally characterizing their effect in cells, to assess specificity and efficacy of drug leads or to identify the targets for drugs of unknown mechanisms of action [1,251]. In Table 4, some examples of recently used cellular arrays in the field of drug screening are shown. For drug screening applications, microfluidic cell microarrays devices are designed to expose one cell type to multiple conditions by individually addressable fluidic streams. Therefore, the cell-array sizes are modest but the exposure of different concentrations of a compound to the same cell-array is favored by the use of an on-chip gradient generator or the same cell array could be exposed to various compounds in parallel screening channels/chambers. Digital microfluidics has been used to screen for the effect of antifungal drugs on non-adherent $S$. cerevisiae cells, which were patterned in a high-density microwell array [252].

Toxicology applications. Toxicology studies are performed in a high-throughput manner with the use of cellular arrays. As for the case of drug screening, the cell array of one cell type is exposed to a concentration gradient of the compound, which is usually generated by a gradient generator (Table 4). This approach allows determining the half maximal inhibitory concentration ( $\mathrm{IC}_{50}$ ) or/and lethal concentration 50 (LC50) on the chip [253].

Cell biology applications. Cell microarrays are being developed for various cellular analyses including the effects of gene expression, cellular reactions to the biomolecular environment, and profiling of cell surface molecules [251]. In the field of cell biology and microbiology, cellular arrays are more and more used to study cellular behavior. One interesting phenomenon is that mammalian cells change their phenotype dramatically depending on their environment. Not only the medium that is added to the cells, but also cues emanating from the extra-cellular matrix, direct cell-cell contacts and mechanical forces control cell behavior [194]. Many examples of the use of cellular arrays in cell biology 
research are published [3,4,254-257] (Table 4). In one example, human hematopoietic stem cells (hHSCs) were introduced in a large array of 2D no-flow chambers to protect the biological sample from fluid flow. In order to determine their stage in the hematopoiesis differentiation pathway, the cells were stained with fluorescent antibodies targeting various surface receptors known to reveal the cell differentiation state [258].

Microbiology research applications. Microfluidic devices and automation of small-scale bioprocesses have received increased interest in the last decade [259]. Microbial single-cell analysis in microfluidic devices has shown potential in several fields of process and strains development such as growth and morphology analysis, population heterogeneity of production strains regarding growth, fitness and single-cell productivity, optimizing process conditions and analysis of cellular response to defined constant environmental conditions, cellular behavior and cell-to-cell heterogeneity at defined concentration gradients and dynamic environments, highly parallelized systems for strain characterisation and screening [120,260-265]. Microsystems have been used to screen and optimize conditions for yeast and E. coli fermentation and growth during processing [266]. Microfluidic bioreactors have been miniaturized to create nanoliter growth chambers in which cell populations can be monitored [112,114]. The use of small reactor volumes and multiple independent cell populations helps to decrease problems associated with genetic variation and makes it possible to assess many conditions in parallel. Optical sensors can be integrated in growth chambers to monitor key process variables such as $\mathrm{pH}$, dissolved oxygen and biomass $\left(\mathrm{OD}_{600 \mathrm{~nm}}\right)$ [267]. High-throughput growth physiology can be combined with global gene expression data analysis and metabolic studies to rapidly prototype and then scale up conditions for industrial bioprocessing [268].

Table 4 and 5 shows some examples of the use of cell arrays in the field of microbiology. Most microbiology studies using cellular microarrays make use of cell arrays that consist of a population of cell type variants (Table 5). In these examples, a large population cell array is exposed to the same fluidic condition. This approach allows extracting dynamic information of the genome or proteome, which is an interesting method to perform systems biology. 
Table 4. Examples of living-cellular microarrays in microfluidic chips: cell arrays of 1 cell type subdivided in adherent and non-adherent cells.

\begin{tabular}{|c|c|c|c|c|c|c|}
\hline Scope & Measurement & Cell Type & $\begin{array}{c}\text { Cell-Array } \\
\text { Type/Methodology }\end{array}$ & Cell-Array Size & Fluidic Conditions & Refs \\
\hline \multicolumn{7}{|c|}{ Adherent Cell Types } \\
\hline $\begin{array}{l}\text { Drug screening: } \\
\text { high-content analysis of cell } \\
\text { signaling }\end{array}$ & $\begin{array}{l}\text { On chip off-line immune- } \\
\text { cytochemistry. }\end{array}$ & $\begin{array}{l}\text { Mouse fibroblasts } \\
\text { (NIH-3T3) }\end{array}$ & $\begin{array}{l}\text { Mechanical cell } \\
\text { patterning (PDMS } \\
\text { microchambers) }\end{array}$ & $\begin{array}{c}32(4 \times 8) \\
4 \text { groups of } 8 \text { parallel } \\
\text { channel chambers; } 8 \\
\text { chambers for each parallel } \\
\text { channel }\end{array}$ & $\begin{array}{l}4 \text { common inlets for } 32 \\
\text { parallel channel chambers } \\
\text { and } 1 \text { additional inlet for a } \\
\text { group of } 8 \text { channels }\end{array}$ & {$[118]$} \\
\hline $\begin{array}{c}\text { Drug screening: screening } \\
\text { of chemotherapeutic } \\
\text { compounds }\end{array}$ & $\begin{array}{l}\text { Cell imaging with } \\
\text { fluorescence microscopy }\end{array}$ & $\begin{array}{c}\text { Human breast cancer } \\
(\mathrm{MCF}-7) \text { and HepG2 } \\
\text { cell lines }\end{array}$ & $\begin{array}{l}\text { Mechanical cell } \\
\text { patterning (PDMS } \\
\text { microchambers) }\end{array}$ & $\begin{array}{c}24(4 \times 6) \\
4 \text { channels rows containing } \\
6 \text { microchambers columns }\end{array}$ & $\begin{array}{c}1 \text { inlet (from gradient } \\
\text { generator) for each column } \\
\text { of } 4 \text { microchambers }\end{array}$ & {$[253]$} \\
\hline Cytotoxicity evaluation & $\begin{array}{l}\text { Real-time microscopy, } \\
\text { albumin concentration } \\
\text { determination in the } \\
\text { effluent (ELISA assay) }\end{array}$ & $\begin{array}{l}\text { Rat hepatocytes in } \\
\text { coculture with } \\
\text { fibroblasts (3T3-J2) }\end{array}$ & $\begin{array}{c}\text { Cell patterning on } \\
\text { adhesive micropatterns } \\
\text { (collagen) in a culture } \\
\text { chamber (glass bottom, } \\
\text { PDMS walls) }\end{array}$ & $\begin{array}{l}\quad 64(8 \times 8) \\
8 \text { rows and } 8 \text { columns of } \\
\text { culture chambers }\end{array}$ & $\begin{array}{l}1 \text { medium inlet for each } \\
\text { row of, culture chambers } \\
\text { and } 1 \text { gas perfusion inlet } \\
\text { for each column of } \\
\text { chambers } \\
\end{array}$ & {$[173]$} \\
\hline Cytotoxicity evaluation & $\begin{array}{l}\text { Real-time cell viability } \\
\text { screening by fluorescence } \\
\text { microscopy }\end{array}$ & $\begin{array}{c}\text { Human lung } \\
\text { carcinoma (A549) } \\
\text { cell line }\end{array}$ & $\begin{array}{c}\text { Mechanical cell } \\
\text { patterning in } \\
\text { microchamber (PDMS } \\
\text { with glass bottom) } \\
\end{array}$ & $\begin{array}{c}25(5 \times 5) \\
5 \text { parallel channels } \\
\text { containing } 5 \text { chambers in } \\
\text { series }\end{array}$ & $\begin{array}{l}2 \text { inlets into a gradient } \\
\text { concentrator that feeds } \\
\text { each parallel channel }\end{array}$ & {$[269]$} \\
\hline Cytotoxicity evaluation & $\begin{array}{l}\text { Fluorescent measurement } \\
\text { (microscopy) of cytosolic } \\
\text { calcium }\end{array}$ & $\begin{array}{l}\text { Mouse leukemic } \\
\text { monocyte } \\
\text { macrophage (RAW) } \\
\text { cell line } \\
\end{array}$ & $\begin{array}{l}\text { Mechanical cell trap } \\
\text { barrier (glass) }\end{array}$ & 1 chamber & 1 inlet & {$[270]$} \\
\hline Cytotoxicity evaluation & $\begin{array}{l}\text { Fluorescent measurement } \\
\text { (microscopy) of cell } \\
\text { viability (ethidium } \\
\text { homodimer-1) }\end{array}$ & $\begin{array}{c}\text { Human HeLa cancer } \\
\text { cell line }\end{array}$ & $\begin{array}{c}\text { Mechanical cell } \\
\text { patterning (PDMS } \\
\text { microwells) }\end{array}$ & $\begin{array}{c}3000(500 \times 6) \\
500 \text { microwells in each } \\
\text { parallel channel }\end{array}$ & $\begin{array}{c}1 \text { chemical inlet followed } \\
\text { by a gradient generator, } \\
\text { which feeds a different } \\
\text { concentration in each } \\
\text { parallel channel }\end{array}$ & {$[271]$} \\
\hline
\end{tabular}


Table 4. Cont.

\begin{tabular}{|c|c|c|c|c|c|c|}
\hline Scope & Measurement & Cell Type & $\begin{array}{c}\text { Cell-Array } \\
\text { Type/Methodology }\end{array}$ & Cell-Array Size & Fluidic Conditions & Refs \\
\hline $\begin{array}{l}\text { Cell biology research: } \\
\text { analysis of cell proliferation } \\
\text { and migration }\end{array}$ & $\begin{array}{l}\text { Cell number and position } \\
\text { (microscopy) }\end{array}$ & $\begin{array}{l}\text { Human breast cancer } \\
\text { cells (MDA-MB-231) }\end{array}$ & $\begin{array}{c}\text { Mechanical cell } \\
\text { patterning in } \\
\text { microchambers (PDSE }{ }^{1} \\
\text { and AZ4562 photoresist) }\end{array}$ & $\begin{array}{l}1600(40 \times 40) \\
\text { Each chamber is linked } \\
\text { together by channels }\end{array}$ & 1 inlet for all chambers & {$[272]$} \\
\hline $\begin{array}{l}\text { Cell biology research: long- } \\
\text { term cellular monitoring for } \\
\text { high-throughput cell-based } \\
\text { assays }\end{array}$ & $\begin{array}{c}\text { Fluorescence localization } \\
\text { of calcein AM } \\
\text { (microscopy) }\end{array}$ & $\begin{array}{c}\text { Human HeLa cancer } \\
\text { cell line }\end{array}$ & $\begin{array}{l}\text { Mechanical cell trap } \\
\text { barrier (PDMS) }\end{array}$ & $\begin{array}{l}100(10 \times 10) \\
10 \text { culture chambers row } \\
\text { and per column }\end{array}$ & $\begin{array}{l}1 \text { inlet per column (from a } \\
\text { gradient generator) and } 1 \\
\text { inlet for all rows }\end{array}$ & {$[22]$} \\
\hline $\begin{array}{c}\text { Cell biology research: } \\
\text { continuous monitoring of } \\
\text { gene expression }\end{array}$ & $\begin{array}{c}\text { Fluorescence microscopy } \\
\text { of eGFP-tagged reporter } \\
\text { gene }\end{array}$ & $\begin{array}{c}\text { Human HeLa cancer } \\
\text { cell line }\end{array}$ & $\begin{array}{c}\text { Mechanical cell } \\
\text { patterning in } \\
\text { microchambers (PDMS) } \\
\end{array}$ & $\begin{array}{l}40(8 \times 5) \\
5 \text { microchambers for each } \\
\text { of the } 8 \text { parallel channels }\end{array}$ & $\begin{array}{l}1 \text { inlet per parallel channel } \\
\text { (from a gradient generator) }\end{array}$ & {$[273]$} \\
\hline $\begin{array}{l}\text { Cell biology research: } \\
\text { adherent cell culture over a } \\
\text { logarithmic range of flow } \\
\text { rates }\end{array}$ & $\begin{array}{l}\text { Cell number and } \\
\text { morphology (microscopy) }\end{array}$ & $\begin{array}{l}\text { Fibroblasts } 3 \mathrm{~T} 3 \text { cell } \\
\text { line }\end{array}$ & $\begin{array}{c}\text { Mechanical cell } \\
\text { patterning in } \\
\text { microchambers (PDMS } \\
\text { with glass bottom) }\end{array}$ & $\begin{array}{l}16(4 \times 4) \\
4 \text { groups of } 4 \text { chambers in } \\
\text { parallel (including the } \\
\text { logarithmic diluter) }\end{array}$ & $\begin{array}{c}1 \text { input per group of } 4 \\
\text { chambers }\end{array}$ & {$[274]$} \\
\hline $\begin{array}{l}\text { Cell biology research: fully } \\
\text { automated cell culture } \\
\text { screening system }\end{array}$ & $\begin{array}{c}\text { Differentiation and } \\
\text { proliferation; cell } \\
\text { number/morphology, cell } \\
\text { nucleus staining, alkaline } \\
\text { phosphatase activity } \\
\text { (microscopy) }\end{array}$ & $\begin{array}{l}\text { Human mesenchymal } \\
\text { stem cells }\end{array}$ & $\begin{array}{c}\text { Mechanical cell } \\
\text { patterning in } \\
\text { microchambers (PDMS) }\end{array}$ & $\begin{array}{c}96(2 \times 48) \\
2 \text { rows of } 48 \text { parallel } \\
\text { chambers }\end{array}$ & 16 inlets per row & {$[116]$} \\
\hline $\begin{array}{l}\text { Cell biology research: real- } \\
\text { time gene expression } \\
\text { monitoring }\end{array}$ & $\begin{array}{c}\text { Fluorescence microscopy } \\
\text { of eGFP-tagged genes }\end{array}$ & $\begin{array}{l}\text { Hepatocytes }(\mathrm{H} 35) \\
\text { cell line }\end{array}$ & $\begin{array}{c}\text { Mechanical cell } \\
\text { patterning in } \\
\text { microchambers (PDMS) }\end{array}$ & $\begin{array}{c}256(8 \times 8 \times 4) \\
8 \text { rows and } 8 \text { columns; } \\
\text { each matrix point is } \\
\text { composed of a } 2 \times 2 \\
\text { subarray }\end{array}$ & $\begin{array}{c}8 \text { inlets for each row and } 8 \\
\text { inlets for each column }\end{array}$ & {$[117]$} \\
\hline
\end{tabular}


Table 4. Cont.

\begin{tabular}{|c|c|c|c|c|c|c|}
\hline Scope & Measurement & Cell Type & $\begin{array}{c}\text { Cell-Array } \\
\text { Type/Methodology }\end{array}$ & Cell-Array Size & Fluidic Conditions & Refs \\
\hline \multicolumn{7}{|c|}{ Non-Adherent Cell Types } \\
\hline $\begin{array}{c}\text { Drug screening: antifungal } \\
\text { evaluation }\end{array}$ & $\begin{array}{l}\text { Effect of antifungal on } \\
\text { viability (fluorescence } \\
\text { microscopy) }\end{array}$ & $\begin{array}{l}\text { Saccharomyces } \\
\text { cerevisiae }\end{array}$ & $\begin{array}{c}\text { Mechanical cell } \\
\text { patterning in microwells } \\
\text { (glass) }\end{array}$ & $\begin{array}{c}44,000(2 \times 22,000) \\
\text { Two arrays of } 22,000 \\
\text { microwells }\end{array}$ & $\begin{array}{l}\text { Digital microfluidic } \\
\text { platform: microwell } \\
\text { seeding by shuttling a cell- } \\
\text { containing droplet; droplet } \\
\text { of antifungal on the array. }\end{array}$ & {$[252]$} \\
\hline $\begin{array}{l}\text { Drug screening: real-time } \\
\text { screening of anticancer } \\
\text { drugs }\end{array}$ & $\begin{array}{l}\text { Online fluorescence } \\
\text { imaging }\end{array}$ & $\begin{array}{l}\text { Human histiocytic } \\
\text { leukaemia (U937) } \\
\text { and promyelocytic } \\
\text { leukaemia } \\
\text { (HL60) cell lines }\end{array}$ & $\begin{array}{c}\text { Mechanical cell trap } \\
\text { barrier (PDMS) }\end{array}$ & $\begin{array}{l}440 \\
\text { All traps in a triangular } \\
\text { chambers }\end{array}$ & $\begin{array}{c}1 \text { inlet and } 6 \text { outlets (base } \\
\text { of the triangle). }\end{array}$ & [23] \\
\hline $\begin{array}{l}\text { Cell biology research: High- } \\
\text { throughput analysis of } \\
\text { single hematopoietic stem } \\
\text { cell proliferation }\end{array}$ & $\begin{array}{c}\text { Proliferation; cell } \\
\text { number/morphology; live- } \\
\text { cell immunostaining; } \\
\text { microscopy }\end{array}$ & $\begin{array}{l}\text { Hemapoietic stem } \\
\text { cells (HSC) (clonal } \\
\text { population) } \\
\text { Preleukemic mouse } \\
\text { (ND13) } \\
\end{array}$ & $\begin{array}{c}\text { Mechanical cell } \\
\text { patterning in } \\
\text { microchambers (PDMS) }\end{array}$ & $\begin{array}{c}6144(64 \times 96) \\
64 \text { parallel channels } \\
(\text { rows); each channels } \\
\text { flows over } 96 \text { wells } \\
(\text { columns })\end{array}$ & $\begin{array}{l}1 \text { inlet for each channel; up } \\
\text { to } 6 \text { different medium } \\
\text { conditions can be loaded }\end{array}$ & [119] \\
\hline $\begin{array}{l}\text { Microbiology research: } \\
\text { long-term monitoring of } \\
\text { bacteria undergoing } \\
\text { programmed population } \\
\text { control in a microchemostat }\end{array}$ & Cell number (microscopy) & Escherichia coli & $\begin{array}{c}\text { Mechanical cell } \\
\text { patterning in } \\
\text { microchambers (PDMS) }\end{array}$ & 6 & $\begin{array}{c}\text { Multiple inlets for each } \\
\text { culture chamber. Culture } \\
\text { chambers are } \\
\text { independently operated } \\
\text { (including an on chip } \\
\text { peristaltic pump). }\end{array}$ & [112] \\
\hline $\begin{array}{l}\text { Microbiology research: } \\
\text { microfluidic chemostat } \\
\text { growth to high cell densities }\end{array}$ & Cell number (microscopy) & $\begin{array}{l}\text { E. coli, } \\
\text { S. cerevisiae }\end{array}$ & $\begin{array}{c}\text { Mechanical cell } \\
\text { patterning in } \\
\text { microchambers (PDMS) }\end{array}$ & $\begin{array}{c}320(16 \times 20) \\
16 \text { parallel channels } \\
\text { containing } 20 \text { chambers }\end{array}$ & $\begin{array}{l}1 \text { inlet branching into the } \\
\text { array of } 16 \text { parallel } \\
\text { channels }\end{array}$ & {$[114]$} \\
\hline
\end{tabular}


Table 4. Cont.

\begin{tabular}{|c|c|c|c|c|c|c|}
\hline Scope & Measurement & Cell Type & $\begin{array}{c}\text { Cell-Array } \\
\text { Type/Methodology }\end{array}$ & Cell-Array Size & Fluidic Conditions & Refs \\
\hline $\begin{array}{l}\text { Microbiology research: } \\
\text { high-throughput time-course } \\
\text { analysis of single cell } \\
\text { responses }\end{array}$ & $\begin{array}{l}\text { Cell number, fluorescent } \\
\text { reporter proteins } \\
\text { (microscopy) }\end{array}$ & S. cerevisiae & $\begin{array}{l}\text { Mechanical cell } \\
\text { patterning in microwells } \\
\text { (polyurethane acrylate) }\end{array}$ & $\begin{array}{c}3906 \text { wells per } \mathrm{mm}^{2} \\
\text { (microwell diameter of } 8 \\
\mu \mathrm{m})\end{array}$ & $\begin{array}{l}1 \text { inlet to channel that } \\
\text { flows over the wells }\end{array}$ & {$[275]$} \\
\hline $\begin{array}{l}\text { Microbiology research: } \\
\text { microscopic observation of } \\
\text { cell behavior at high } \\
\text { resolution }\end{array}$ & $\begin{array}{l}\text { Cell number/morphology } \\
\text { and single molecule } \\
\text { fluorescence imaging } \\
\text { (microscopy) }\end{array}$ & $\begin{array}{l}\text { Schizosaccharo- } \\
\text { myces pombe }\end{array}$ & $\begin{array}{l}\text { Mechanical cell trap } \\
\text { barrier (PDMS) }\end{array}$ & $\begin{array}{c}7728(4 \times 1932) \\
4 \text { trapping regions, each } \\
\text { with } 1932 \text { mechanical cell } \\
\text { traps }\end{array}$ & $\begin{array}{c}3 \text { inlets feeding into } 4 \\
\text { trapping regions }\end{array}$ & [120] \\
\hline $\begin{array}{l}\text { Microbiology research: } \\
\text { spatio-temporal analysis of } \\
\text { growing bacterial } \\
\text { microcolonies in perfusion } \\
\text { reactor }\end{array}$ & $\begin{array}{c}\text { Cell number and } \\
\text { morphology (microscopy) }\end{array}$ & $\begin{array}{c}\text { E. coli } \\
\text { Corynebacterium } \\
\text { glutamicum }\end{array}$ & $\begin{array}{c}\text { Mechanical cell trap } \\
\text { barrier (PDMS) }\end{array}$ & $\begin{array}{c}30(6 \times 5) \\
6 \text { parallel channel } \\
\text { containing each } 5 \text { cell trap } \\
\text { barriers }\end{array}$ & $\begin{array}{l}2 \text { inlets into a gradient } \\
\text { generator, which feeds } \\
\text { each parallel channel }\end{array}$ & $\begin{array}{c}{[265,27} \\
6]\end{array}$ \\
\hline
\end{tabular}

${ }^{1}$ PDSE: photodefinable silicon elastomer.

Table 5. Examples of living-cellular microarrays in microfluidic chips: cell arrays of a population cell type variants.

\begin{tabular}{|c|c|c|c|c|c|c|c|}
\hline Scope & Measurement & Cell Type & Populationsize & $\begin{array}{c}\text { Cell-Array } \\
\text { Type/Methodology }\end{array}$ & Cell-Array Size & Fluidic Conditions & Refs \\
\hline \multicolumn{8}{|c|}{ Adherent Cell Types } \\
\hline $\begin{array}{l}\text { Cell biology research: cell } \\
\text { culture device (multiple } \\
\text { cycles of growth and } \\
\text { trypsinization) }\end{array}$ & $\begin{array}{c}\text { Microscopic observation } \\
\text { of cell morphology and } \\
\text { viability }\end{array}$ & $\begin{array}{c}\text { Murine } \\
\text { embryonic } \\
\text { fibroblast } \\
\text { (BALB/3T3) }\end{array}$ & 1 to 8 & $\begin{array}{c}\text { Mechanical cell } \\
\text { patterning ( } 8 \\
\text { mechanical cell trap } \\
\text { barriers in } \\
\text { PDMS/chamber) }\end{array}$ & $\begin{array}{c}64(8 \times 8) \\
8 \text { parallel } \\
\text { independent rows; } 8 \\
\text { cultivation } \\
\text { chambers in series } \\
\text { per row }\end{array}$ & $\begin{array}{l}1 \text { inlet for } 1 \text { parallel } \\
\text { channel }\end{array}$ & {$[277]$} \\
\hline
\end{tabular}


Table 5. Cont.

\begin{tabular}{|c|c|c|c|c|c|c|c|}
\hline Scope & Measurement & Cell Type & Populationsize & $\begin{array}{c}\text { Cell-Array } \\
\text { Type/Methodology }\end{array}$ & Cell-Array Size & Fluidic Conditions & Refs \\
\hline \multicolumn{8}{|c|}{ Non-Adherent Cell Types } \\
\hline $\begin{array}{c}\text { Microbiology research: } \\
\text { studying signaling network } \\
\text { dynamics }\end{array}$ & $\begin{array}{l}\text { Time-lapse cell imaging; } \\
\text { heme expression by } \\
\text { genetically encoded GFP } \\
\text { reporter and protein } \\
\text { localization (GFP-tagged } \\
\text { protein) }\end{array}$ & S. cerevisiae & 8 strains & $\begin{array}{l}\text { Mechanical cell } \\
\text { patterning (PDMS } \\
\text { microchambers) }\end{array}$ & $128(8 \times 16)$ & $\begin{array}{l}8 \text { chemical inlets for } \\
16 \text { parallel rows }\end{array}$ & {$[195]$} \\
\hline $\begin{array}{l}\text { Microbiology research: } \\
\text { spatio-temporal analysis of } \\
\text { the proteome }\end{array}$ & $\begin{array}{l}\text { Time lapse imaging of } \\
\text { GFP-tagged strains }\end{array}$ & S. cerevisiae & 1152 strains & $\begin{array}{l}\text { Direct cell printing } \\
\text { and mechanical } \\
\text { trapping in } \\
\text { microchemostat } \\
\text { chambers (PDMS) }\end{array}$ & $\begin{array}{c}1152(3 \times 384) \\
3 \text { independent } \\
\text { sections of } 384 \\
\text { chambers }\end{array}$ & $\begin{array}{l}1 \text { inlet per chamber } \\
\text { section }\end{array}$ & {$[202]$} \\
\hline $\begin{array}{l}\text { Microbiology research: } \\
\text { monitor biofilm formation } \\
\text { under near-native conditions }\end{array}$ & $\begin{array}{l}\text { Quantitative cell analysis } \\
\text { by bio-impedance } \\
\text { measurement and } \\
\text { respiration activity } \\
\text { measured by } \\
\text { electrochemical } \\
\text { microelectrodes }\end{array}$ & $\begin{array}{l}\text { Candida } \\
\text { albicans }\end{array}$ & 2 & $\begin{array}{l}\text { Mechanical cell } \\
\text { patterning (PDMS } \\
\text { microchambers) }\end{array}$ & 2 & 1 inlet per chamber & {$[278]$} \\
\hline $\begin{array}{l}\text { Microbiology research: detect } \\
\text { cellular dynamics in response } \\
\text { to drugs and chemicals }\end{array}$ & $\begin{array}{c}\text { Cell number and } \\
\text { fluorescent imaging of } \\
\text { protein tagged proteins } \\
\text { (microscopy) }\end{array}$ & S. cerevisiae & 2 & $\begin{array}{l}\text { Direct cell printing } \\
\text { on agarose-coated } \\
\text { glass }\end{array}$ & $\begin{array}{l}10,000(100 \times 100) \\
\text { Spot sizes of } \\
\text { around } 200 \mu \mathrm{m}\end{array}$ & $\begin{array}{l}1 \text { inlet, channel over } \\
\text { all spots }\end{array}$ & {$[56]$} \\
\hline
\end{tabular}




\section{Conclusions and Outlook}

It has become increasingly clear in the trends in scientific research that microscale cellular microarrays will have an increasing role in cell biology research. This is due to the many advantages that cellular microarrays approaches could possibly have over traditional cell assays. This review is focused on the integration of cellular microarrays in microfluidic bioreactors that allow analyzing the dynamic behavior of cells at the single-cell level. The design and construction of the microfluidic bioreactors are discussed. The different cell arraying methods are reviewed and discussed with a focus on cell patterning on adhesive micropatterns, mechanical cell patterning in microwells, microchambers and mechanical cell trap barriers, and robotic cell printing techniques. Selection criteria are provided to guide the selection. We point to differences between the construction of 2D or 3D cell microarrays. Finally, the microfluidic operation of these devices and single-cell measurements are discussed. Dependent on the scope of the cell assay, microfluidic cell microarray devices can be designed to obtain a high throughput (1) by the parallel screening of a concentration gradient of a compound or multiple compounds for a one-cell type array; or (2) by the simultaneous screening of one compound for various cell types in the cell array. Both strategies are illustrated by examples in the fields of drug screening, toxicology, and basic cell biology and microbiology research.

The microfluidic cellular microarrays were initially 2D systems. Later on, 3D systems were introduced to cultivate mammalian cells since the cell's microenvironment in $3 \mathrm{D}$ can mimic the characteristics of a tissue in vivo. This is particularly of interest when the behavior of cells is strongly influenced by the microenvironment, i.e., during cell proliferation, differentiation and cell-cell communication. We discussed the cell patterning methods to conduct 3D on-top or 3D cell embedded cultures. 3D cell embedded systems provide the best 3D microenvironment. 3D cell microarrays can be constructed by using bioprinting techniques. Hereto, cell arrays can be printed in microfluidic channels with consequent closing of the device.

Future challenges lie in the construction of extended cell microarrays and integration in the microfluidic chip. Current cell arraying methods based on closed microchambers arrays in microfluidic bioreactors increase throughput compared to classical multiwell plate cell assays with significantly reduced amounts spent on expensive test reagents, cells and chemical compounds. However, interfacing capabilities are currently limiting. Therefore, new interfacing solutions are needed to increase the throughput where array elements need to be addressed individually. Robotic cell patterning in microfluidic chips is a promising technique to construct cell arrays composed of a population of cell variants. These arrays could allow analyzing cells dynamically on a whole transcriptome or proteome level. Future technological challenges lie in the further development of the technology and procedures to construct these genome/proteome-wide cell microarrays.

This enabling technology for integrated total single-cell analysis has not yet gained popular acceptance. Microfluidic chip manufacturing and patterning techniques are not easy accessible for cell biology labs since complex technology and equipment, which is costly and requires specific expertise, is needed. Further development of the technology needs a multidisciplinary approach with significant input from the cell biology community. Recently, some companies have offered commercial microfluidic chips that can be used to produce microfluidic cell microarrays by the scientific community. 
This will stimulate its wider use and further development. Finally, this technology could revolutionize cell biology research and downstream applications such as drug discovery.

\section{Acknowledgments}

The Belgian Federal Science Policy Office (Belspo), the European Space Agency (ESA) PRODEX program and the Research Council of the Vrije Universiteit Brussel supported this work.

\section{Conflicts of Interest}

The authors declare no conflict of interest.

\section{References}

1. Castel, D.; Pitaval, A.; Debily, M.A.; Gidrol, X. Cell microarrays in drug discovery. Drug Discov. Today 2006, 13-14, 616-622.

2. Chen, D.S.; Davis, M.M. Molecular and functional analysis using live cell microarrays. Curr. Opin. Chem. Biol. 2006, 10, 28-34.

3. Yarmush, M.L.; King, K.R. Living-cell microarrays. Annu. Rev. Biomed. Eng. 2009, 11, 235-257.

4. Velve-Casquillas, G.; le Berre, M.; Piel, M.; Tran, P.T. Microfluidic tools for cell biological research. Nano Today 2010, 5, 28-47.

5. Sackmann, E.K.; Fulton, A.L.; Beebe, D.J. The present and future role of microfluidics in biomedical research. Nature 2014, 507, 181-189.

6. Kim, D.; Wu, X.; Young, A.T.; Haynes, C.L. Microfluidics-based in vivo mimetic systems for the study of cellular biology. Acc. Chem. Res. 2014, 47, 1165-1173.

7. Mehling, M.; Tay, S. Microfluidic cell culture. Curr. Opin. Biotechnol. 2014, 25, 95-102.

8. Fernandes, T.G.; Diogo, M.M.; Clark, D.S.; Dordick, J.S.; Cabral, J.M. High-throughput cellular microarray platforms: Applications in drug discovery, toxicology and stem cell research. Trends Biotechnol. 2009, 27, 342-349.

9. Gidrol, X.; Fouqué, B.; Ghenim, L.; Haguet, V.; Picollet-D’hahan, N.; Schaack, B. 2D and 3D cell microarrays in pharmacology. Curr. Opin. Pharmacol. 2009, 9, 664-648.

10. Sia, S.K.; Whitesides, G.M. Microfluidic devices fabricated in poly(dimethylsiloxane) for biological studies. Electrophoresis 2003, 24, 3563-3576.

11. Kim, S.M.; Lee, S.H.; Suh, K.Y. Cell research with physically modified microfluidic channels: A review. Lab Chip 2008, 8, 1015-1023.

12. Yang, M.; Li, C.W.; Yang, J. Cell docking and on-chip monitoring of cellular reactions with a controlled concentration gradient on a microfluidic device. Anal. Chem. 2002, 74, 3991-4001.

13. Li, C.W.; Cheung, C.N.; Yang, J.; Tzang, C.H.; Yang, M. PDMS-based microfluidic device with multi-height structures fabricated by single-step photo lithography using printed circuit board as masters. Analyst 2003, 128, 1137-1142.

14. Zhu, L.; Zhang, Q.; Feng, H.; Ang, S.; Chau, F.S.; Liu, W.T. Filter-based microfluidic device as a platform for immunofluorescent assay of microbial cells. Lab Chip 2004, 4, 337-341. 
15. Valero, A.; Merino, F.; Wolbers, F.; Luttge, R.; Vermes, I.; Andersson, H.; van den Berg, A. Apoptotic cell death dynamics of HL60 cells studied using a microfluidic cell trap device. Lab Chip 2005, 5, 49-55.

16. Di Carlo, D.; Aghdam, N.; Lee, L.P. Single-cell enzyme concentrations, kinetics, and inhibition analysis using high-density hydrodynamic cell isolation arrays. Anal. Chem. 2006, 78, 4925-4930.

17. Fu, A.Y.; Chou, H.P.; Spence, C.; Arnold, F.H.; Quake, S.R. An integrated microfabricated cell sorter. Anal. Chem. 2002, 74, 2451-2457.

18. Wheeler, A.R.; Throndset, W.R.; Whelan, R.J.; Leach, A.M.; Zare, R.N.; Liao, Y.H.; Farrell, K.; Manger, I.D.; Daridon, A. Microfluidic device for single-cell analysis. Anal. Chem. 2003, 75, 3581-3586.

19. Tourovskaia, A.; Figueroa-Masot, X.; Folch, A. Differentiation-on-a-chip: A microfluidic platform for long-term cell culture studies. Lab Chip 2005, 5, 14-19.

20. Ryley, J.; Pereira-Smith, O.M. Microfluidics device for single cell gene expression analysis in Saccharomyces cerevisiae. Yeast 2006, 23, 1065-1073.

21. Unger, M.A.; Chou, H.P.; Thorsen, T.; Scherer, A.; Quake, S.R. Monolithic microfabricated valves and pumps by multilayer soft lithography. Science 2000, 288, 113-116.

22. Hung, P.J.; Lee, P.J.; Sabounchi, P.; Lin, R.; Lee, L.P. Continuous perfusion microfluidic cell culture array for high-throughput cell-based assays. Biotechnol. Bioeng. 2005, 89, 1-8.

23. Wlodkowic, D.; Faley, S.; Zagnoni, M.; Wikswo, J.P.; Cooper, J.M. Microfluidic single-cell array cytometry for the analysis of tumor apoptosis. Anal. Chem. 2009, 81, 5517-5523.

24. Beebe, D.J.; Moore, J.S.; Bauer, J.M.; Yu, Q.; Liu, R.H.; Devadoss, C.; Jo, B.H. Functional hydrogel structures for autonomous flow control inside microfluidic channels. Nature 2000, 404, 588-590.

25. Moorthy, J.; Beebe, D.J. In situ fabricated porous filters for microsystems. Lab Chip 2003, 3, 62-66.

26. Peppas, N.A.; Hilt, J.Z.; Khademhosseini, A.; Langer, R. Hydrogels in biology and medicine: From molecular principles to bionanotechnology. Adv. Mater. 2006, 18, 1345-1360.

27. Khademhosseini, A.; Yeh, J.; Jon, S.; Eng, G.; Suh, K.Y.; Burdick, J.A.; Langer, R. Molded polyethylene glycol microstructures for capturing cells within microfluidic channels. Lab Chip 2004, 4, 425-430.

28. Khademhosseini, A.; Yeh, J.; Eng, G.; Karp, J.; Kaji, H.; Borenstein, J.; Farokhzad, O.C.; Langer, R. Cell docking inside microwells within reversibly sealed microfluidic channels for fabricating multiphenotype cell arrays. Lab Chip 2005, 5, 1380-1386.

29. Love, J.C.; Ronan, J.L.; Grotenberg, G.M.; van der Veen, A.G.; Ploegh, H.L. A microengraving method for rapid selection of single cells producing antigen-specific antibodies. Nat. Biotechnol. 2006, 24, 703-707.

30. Park, M.C.; Hur, J.Y.; Kwon, K.W.; Park, S.H.; Suh, K.Y. Pumpless, selective docking of yeast cells inside a microfluidic channel induced by receding meniscus. Lab Chip 2006, 6, 988-994.

31. Kwon, K.W.; Choi, S.S.; Lee, S.H.; Kim, B.; Lee, S.N.; Park, M.C.; Kim, P.; Hwang, S.Y.; Suh, K.Y. Label-free, microfluidic separation and enrichment of human breast cancer cells by adhesion difference. Lab Chip 2007, 7, 1461-1468.

32. Sant, S.; Hancock, M.J.; Donnelly, J.P.; Iyer, D.; Khademhosseini, A. Biomimetic gradient hydrogels for tissue engineering. Can. J. Chem. Eng. 2010, 88, 899-911. 
33. Rimann, M.; Graf-Hausner, U. Synthetic 3D multicellular systems for drug development. Curr. Opin. Biotechnol. 2012, 23, 803-809.

34. Breslin, S.; O’Driscoll, L. Three-dimensional cell culture: The missing link in drug discovery. Drug Discov. Today 2013, 18, 240-249.

35. Andersen, T.; Auk-Emblem, P.; Dornish, M. 3D cell culture in alginate hydrogels. Microarrays 2015, 4, 133-161.

36. Smidsrød, O.; Skjåk-Braek, G. Alginate as immobilization matrix for cells. Trends Biotechnol. 1990, 8, 71-78.

37. Willaert, R.; Baron, G. Gel entrapment and micro-encapsulation: Methods, applications and engineering principles. Rev. Chem. Eng. 1996, 12, 5-205.

38. Kong, H.J.; Smith, M.K.; Mooney, D.J. Designing alginate hydrogels to maintain viability of immobilized cells. Biomaterials 2003, 24, 4023-4029.

39. Nedovic, V.; Willaert, R. Fundamentals of Cell Immobilisation Biotechnology; Kluwer Academic Publishers: Dordrecht, The Netherlands, 2004.

40. Nedovic, V.; Willaert, R. Applications of Cell Immobilisation Biotechnology; Springer: Dordrecht, The Netherlands, 2005.

41. Zhang, S.; Gelain, F.; Zhao, X. Designer self-assembling peptide nanofiber scaffolds for 3D tissue cell cultures. Semin. Cancer Biol. 2005, 15, 413-420.

42. Altmann, B.; Welle, A.; Giselbrecht, S.; Truckenmüller, R.; Gottwald, E. The famous versus the inconvenient-or the dawn and the rise of 3D-culture systems. World J. Stem Cells 2009, 1, 43-48.

43. DeVolder, R.; Kong, H.J. Hydrogels for in vivo-like three-dimensional cellular studies. Wiley Interdiscip. Rev. Syst. Biol. Med. 2012, 4, 351-365.

44. Willaert, R. Cell immobilisation and its applications in biotechnology: Current trends and future prospects. In Fermentation Microbiology and Biotechnology, 3rd ed.; El-Mansi, E.M.T., Bryce, C.F.A., Eds.; CRC Press: Boca Raton, FL, USA, 2012; pp. 313-367.

45. Luo, Z.; Yue, Y.; Zhang, Y.; Yuan, X.; Gong, J.; Wang, L.; He, B.; Liu, Z.; Sun, Y.; Liu, J.; et al. Designer D-form self-assembling peptide nanofiber scaffolds for 3-dimensional cell cultures. Biomaterials 2013, 34, 4902-4913.

46. Sun, J.; Tan, H. Alginate-based biomaterials for regenerative medicine applications. Materials 2013, 6, 1285-1309.

47. Sánchez, P.; Hernández, R.M.; Pedraz, J.L.; Orive, G. Encapsulation of cells in alginate gels. Methods Mol. Biol. 2013, 1051, 313-325.

48. Ahmed, E.M. Hydrogel: Preparation, characterization, and applications: A review. J. Adv. Res. 2015, 6, 105-121.

49. Montanez-Sauri, S.I.; Beebe, D.J.; Sung, K.E. Microscale screening systems for 3D cellular microenvironments: Platforms, advances, and challenges. Cell. Mol. Life Sci. 2015, 72, 237-249.

50. Otsuka, H.; Hirano, A.; Nagasaki, Y.; Okano, T.; Horiike, Y.; Kataoka, K. Two-dimensional multiarray formation of hepatocyte spheroids on a microfabricated PEG-brush surface. Chembiochem 2004, 5, 850-855.

51. Sung, H.J.; Su, J.; Berglund, J.D.; Russ, B.V.; Meredith, J.C.; Galis, Z.S. The use of temperature-composition combinatorial libraries to study the effects of biodegradable polymer blend surfaces on vascular cells. Biomaterials 2005, 26, 4557-4567. 
52. Simon, C.G., Jr.; Eidelman, N.; Kennedy, S.B.; Sehgal, A.; Khatri, C.A.; Washburn, N.R. Combinatorial screening of cell proliferation on poly(L-lactic acid)/poly(D,L-lactic acid) blends. Biomaterials. 2005, 26, 6906-6915.

53. Khetani, S.R.; Bhatia, S.N. Microscale culture of human liver cells for drug development. Nat. Biotechnol. 2008, 26, 120-126.

54. Sodunke, T.R.; Turner, K.K.; Caldwell, S.A.; McBride, K.W.; Reginato, M.J.; Noh, H.M. Micropatterns of Matrigel for three-dimensional epithelial cultures. Biomaterials 2007, 28, 4006-4016.

55. Flaim, C.J.; Teng, D.; Chien, S.; Bhatia, S.N. Combinatorial signaling microenvironments for studying stem cell fate. Stem Cells Dev. 2008, 17, 29-39.

56. Mirzaei, M.; Pla-Roca, M.; Safavieh, R.; Nazarova, E.; Safavieh, M.; Li, H.; Vogel, J.; Juncker, D. Microfluidic perfusion system for culturing and imaging yeast cell microarrays and rapidly exchanging media. Lab Chip 2010, 10, 2449-2457.

57. Huang, S.B.; Wu, M.H.; Wang, S.S.; Lee, G.B. Microfluidic cell culture chip with multiplexed medium delivery and efficient cell/scaffold loading mechanisms for high-throughput perfusion 3-dimensional cell culture-based assays. Biomed. Microdevices 2011, 13, 415-430.

58. Dos Reis, G.; Fenili, F.; Gianfelice, A.; Bongiorno, G.; Marchesi, D.; Scopelliti, P.E.; Borgonovo, A.; Podestà, A.; Indrieri, M.; Ranucci, E.; et al. Direct microfabrication of topographical and chemical cues for the guided growth of neural cell networks on polyamidoamine hydrogels. Macromol. Biosci. 2010, 10, 842-852.

59. Skardal, A.; Atala, A. Biomaterials for integration with 3-D bioprinting. Ann. Biomed. Eng. 2015, 43, 730-746.

60. Lee, M.Y.; Kumar, R.A.; Sukumaran, S.M.; Hogg, M.G.; Clark, D.S.; Dordick, J.S. Three-dimensional cellular microarray for high-throughput toxicology assays. Proc. Natl. Acad. Sci. USA 2008, 105, 59-63.

61. Fernandes, T.G.; Kwon, S.J.; Bale, S.S.; Lee, M.Y.; Diogo, M.M.; Clark, D.S.; Cabral, J.M.; Dordick, J.S. Three-dimensional cell culture microarray for high-throughput studies of stem cell fate. Biotechnol. Bioeng. 2010, 106, 106-118.

62. Meli, L.; Jordan, E.T.; Clark, D.S.; Linhardt, R.J.; Dordick, J.S. Influence of a three-dimensional, microarray environment on human cell culture in drug screening systems. Biomaterials 2012, 33, 9087-9096.

63. Guo, L.J. Nanoimprint Lithography: Methods and Material Requirements. Adv. Mater. 2007, 19, 495-513.

64. Yap, F.L.; Zhang, Y. Protein and cell micropatterning and its integration with micro/nanoparticles assembly. Biosens. Bioelectron. 2007, 22, 775-788.

65. Anselme, K.; Davidson, P.; Popa, A.M.; Giazzon, M.; Liley, M.; Ploux, L. The interaction of cells and bacteria with surfaces structured at the nanometre scale. Acta Biomater. 2010, 6, 3824-3846.

66. Qin, D.; Xia, Y.; Whitesides, G.M. Soft lithography for micro- and nanoscale patterning. Nat. Protoc. 2010, 5, 491-502.

67. Ekerdt, B.L.; Segalman, R.A.; Schaffer, D.V. Spatial organization of cell-adhesive ligands for advanced cell culture. Biotechnol. J. 2013, 8, 1411-1423. 
68. Singh, A.V.; Patil, R.; Thombre, D.K.; Gade, W.N. Micro-nanopatterning as tool to study the role of physicochemical properties on cell-surface interactions. J. Biomed. Mater. Res. A 2013, 101, 3019-3032.

69. Ruiz, S.A.; Chen, C.S. Microcontact printing: A tool to pattern. Soft Matter. 2007, 3, 168-177.

70. Mrksich, M. Using self-assembled monolayers to model the extracellular matrix. Acta Biomater. 2009, 5, 832-841.

71. Théry, M.; Piel, M. Adhesive micropatterns for cells: A microcontact printing protocol. Cold Spring Harb. Protoc. 2009, 7, doi:10.1101/901.

72. Nakanishi, J.; Takarada, T.; Yamaguchi, K.; Maeda, M. Recent advances in cell micropatterning techniques for bioanalytical and biomedical sciences. Anal. Sci. 2008, 24, 67-72.

73. D'Arcangelo, E.; McGuigan, A.P. Micropatterning strategies to engineer controlled cell and tissue architecture in vitro. Biotechniques 2015, 58, 13-23.

74. McFarland, C.D.; Thomas, C.H.; DeFilippis, C.; Steele, J.G.; Healy, K.E. Protein adsorption and cell attachment to patterned surfaces. J. Biomed. Mater. Res. 2000, 49, 200-210.

75. Falconnet, D.; Csucs, G.; Grandin, H.M.; Textor, M. Surface engineering approaches to micropattern surfaces for cell-based assays. Biomaterials 2006, 27, 3044-3063.

76. Hook, A.L.; Thissen, H.; Voelcker, N.H. Surface manipulation of biomolecules for cell microarray applications. Trends Biotechnol. 2006, 24, 471-477.

77. Otsuka, H. Nanofabrication of nonfouling surfaces for micropatterning of cell and microtissue. Molecules 2010, 15, 5525-5546.

78. Xu, L.; Robert, L.; Ouyang, Q.; Taddei, F.; Chen, Y.; Lindner, A.B.; Baigl, D. Microcontact printing of living bacteria arrays with cellular resolution. Nano Lett. 2007, 7, 2068-2072.

79. Dertinger, S.K.; Jiang, X.; Li, Z.; Murthy, V.N.; Whitesides, G.M. Gradients of substrate-bound laminin orient axonal specification of neurons. Proc. Natl. Acad. Sci. USA 2002, 99, 12542-12547.

80. Cosson, S.; Lutolf, M.P. Microfluidic patterning of protein gradients on biomimetic hydrogel substrates. Methods Cell Biol. 2014, 121, 91-102.

81. Théry, M. Micropatterning as a tool to decipher cell morphogenesis and functions. J. Cell Sci. 2010, 123, 4201-4213.

82. Balakirev, M.Y.; Porte, S.; Vernaz-Gris, M.; Berger, M.; Arié, J.P.; Fouqué, B.; Chatelain, F. Photochemical patterning of biological molecules inside a glass capillary. Anal. Chem. 2005, 77, 5474-5479.

83. Bélisle, J.M.; Correia, J.P.; Wiseman, P.W.; Kennedy, T.E.; Costantino, S. Patterning protein concentration using laser-assisted adsorption by photobleaching, LAPAP. Lab Chip 2008, 8, 2164-2167.

84. Bélisle, J.M.; Kunik, D.; Costantino, S. Rapid multicomponent optical protein patterning. Lab Chip 2009, 9, 3580-3585.

85. Bélisle, J.M.; Mazzaferri, J.; Costantino, S. Laser-assisted adsorption by photobleaching. Methods Cell Biol. 2014, 119, 125-140.

86. Dillmore, W.S.; Yousaf, M.N.; Mrksich, M. A photochemical method for patterning the immobilization of ligands and cells to self-assembled monolayers. Langmuir 2004, 20, 7223-7231. 
87. Kim, M.; Choi, J.C.; Jung, H.R.; Katz, J.S.; Kim, M.G.; Doh, J. Addressable micropatterning of multiple proteins and cells by microscope projection photo lithography based on a protein friendly photoresist. Langmuir 2010, 26, 12112-12118.

88. Fink, J.; Théry, M.; Azioune, A.; Dupont, R.; Chatelain, F.; Bornens, M.; Piel, M. Comparative study and improvement of current cell micro-patterning techniques. Lab Chip 2007, 7, 672-680.

89. Azioune, A.; Storch, M.; Bornens, M.; Théry, M.; Piel, M. Simple and rapid process for single cell micro-patterning. Lab Chip 2009, 9, 1640-1642.

90. Itoga, K.; Kobayashi, J.; Yamato, M.; Okano, T. Micropatterning with a liquid crystal display (LCD) projector. Methods Cell Biol. 2014, 119, 141-158.

91. Doyle, A.D. Generation of micropatterned substrates using micro photopatterning. Curr. Protoc. Cell Biol. 2009, doi: 10.1002/0471143030.cb1015s45.

92. Miller, J.S.; Béthencourt, M.I.; Hahn, M.; Lee, T.R.; West, J.L. Laser-scanning lithography (LSL) for the soft lithographic patterning of cell-adhesive self-assembled monolayers. Biotechnol. Bioeng. 2006, 93, 1060-1068.

93. Slater, J.H.; West, J.L. Fabrication of multifaceted, micropatterned surfaces and image-guided patterning using laser scanning lithography. Methods Cell Biol. 2014, 119, 193-217.

94. Piner, R.D.; Zhu, J.; Xu, F.; Hong, S.; Mirkin, C.A. "Dip-Pen” nanolithography. Science 1999, 283, 661-663.

95. Wu, C.C.; Reinhoudt, D.N.; Otto, C.; Subramaniam, V.; Velders, A.H. Strategies for patterning biomolecules with dip-pen nanolithography. Small 2011, 7, 989-1002.

96. Hirtz, M.; Greiner, A.M.; Landmann, T.; Bastmeyer, M.; Fuchs, H. Click-chemistry based multi-component microarrays by quill-like pens. Adv. Mater. Interfaces 2014; 1, 1300129.

97. Bog, U.; Laue, T.; Grossmann, T.; Beck, T.; Wienhold, T.; Richter, B.; Hirtz, M.; Fuchs, H.; Kalt, H.; Mappes, T. On-chip microlasers for biomolecular detection via highly localized deposition of a multifunctional phospholipid ink. Lab Chip 2013, 13, 2701-2707.

98. Rath, P.; Hirtz, M.; Lewes-Malandrakis, G.; Brink, D.; Nebel, C.; Pernice, W.H.P. Diamond nanophotonic circuits functionalized by dip-pen nanolithography. Adv. Opt. Mater. 2015, 3, 328-335.

99. Huo, F.; Zheng, Z.; Zheng, G.; Giam, L.R.; Zhang, H.; Mirkin, C.A. Polymer pen lithography. Science 2008, 321, 1658-1660.

100. Brinkmann, F.; Hirtz, M.; Greiner, A.M.; Weschenfelder, M.; Waterkotte, B.; Bastmeyer, M.; Fuchs, H. Interdigitated multicolored bioink micropatterns by multiplexed polymer pen lithography. Small 2013, 9, 3266-3275.

101. Truskett, V.N.; Watts, M.P. Trends in imprint lithography for biological applications. Trends Biotechnol. 2006, 24, 312-317.

102. Hu, J.; Shi, J.; Zhang, F.; Lei, L.; Li, X.; Wang, L.; Liub, L.; Chen, Y. High resolution and hybrid patterning for single cell attachment. Microelectron. Eng. 2010, 87, 726-729.

103. Pesen, D.; Erlandsson, A.; Ulfendahl, M.; Haviland, D.B. Image reversal for direct electron beam patterning of protein coated surfaces. Lab Chip 2007, 7, 1603-1606.

104. Rundqvist, J.; Mendoza, B.; Werbin, J.L.; Heinz, W.F.; Lemmon, C.; Romer, L.H.; Haviland, D.B.; Hoh, J.H. High fidelity functional patterns of an extracellular matrix protein by electron beam-based inactivation. J. Am. Chem. Soc. 2007, 129, 59-67. 
105. Krsko, P.; McCann, T.E.; Thach, T.T.; Laabs, T.L.; Geller, H.M.; Libera, M.R. Length-scale mediated adhesion and directed growth of neural cells by surface-patterned poly(ethylene glycol) hydrogels. Biomaterials 2009, 30, 721-729.

106. Medvedev, N.; Palankar, R.; Krauel, K.; Greinacher, A.; Delcea, M. Micropatterned array to assess the interaction of single platelets with platelet factor 4-heparin-IgG complexes. Thromb. Haemost. 2014, 111, 862-872.

107. Yang, S.M.; Jang, S.G.; Choi, D.G.; Kim, S.; Yu, H.K. Nanomachining by colloidal lithography. Small 2006, 2, 458-475.

108. Lim, J.Y.; Donahue, H.J. Cell sensing and response to micro- and nanostructured surfaces produced by chemical and topographic patterning. Tissue Eng. 2007, 8, 1879-1891.

109. Wood, M.A. Colloidal lithography and current fabrication techniques producing in-plane nanotopography for biological applications. J. R. Soc. Interface 2007, 4, 1-17.

110. Dalby, M.J.; McCloy, D.; Robertson, M.; Agheli, H.; Sutherland, D.; Affrossman, S.; Oreffo, R.O. Osteoprogenitor response to semi-ordered and random nanotopographies. Biomaterials 2006, 27, 2980-1987.

111. Rettig, J.R.; Folch, A. Large-scale single-cell trapping and imaging using microwell arrays. Anal. Chem. 2005, 77, 5628-5634.

112. Balagaddé, F.K.; You, L.; Hansen, C.L.; Arnold, F.H.; Quake, S.R. Long-term monitoring of bacteria undergoing programmed population control in a microchemostat. Science 2005, 309, 137-140.

113. Balagaddé, F.K.; Song, H.; Ozaki, J.; Collins, C.H.; Barnet, M.; Arnold, F.H.; Quake, S.R.; You, L. A synthetic Escherichia coli predator-prey ecosystem. Mol. Syst. Biol. 2008, 4, 187.

114. Groisman, A.; Lobo, C.; Cho, H.; Campbell, J.K.; Dufour, Y.S.; Stevens, A.M.; Levchenko, A. A microfluidic chemostat for experiments with bacterial and yeast cells. Nat. Methods 2005, 2, 685-689.

115. Falconnet, D.; Niemistö, A.; Taylor, R.J.; Ricicova, M.; Galitski, T.; Shmulevich, I.; Hansen, C.L. High-throughput tracking of single yeast cells in a microfluidic imaging matrix. Lab Chip 2011, $11,466-473$.

116. Gómez-Sjöberg, R.; Leyrat, A.A.; Pirone, D.M.; Chen, C.S.; Quake, S.R. Versatile, fully automated, microfluidic cell culture system. Anal. Chem. 2007, 79, 8557-8563.

117. King, K.R.; Wang, S.; Irimia, D.; Jayaraman, A.; Toner, M.; Yarmush, M.L. A high-throughput microfluidic real-time gene expression living cell array. Lab Chip 2007, 7, 77-85.

118. Cheong, R.; Wang, C.J.; Levchenko, A. Using a microfluidic device for high-content analysis of cell signaling. Sci. Signal. 2009, 2, 12.

119. Lecault, V.; Vaninsberghe, M.; Sekulovic, S.; Knapp, D.J.; Wohrer, S.; Bowden, W.; Viel, F.; McLaughlin, T.; Jarandehei, A.; Miller, M.; et al. High-throughput analysis of single hematopoietic stem cell proliferation in microfluidic cell culture arrays. Nat. Methods 2011, 8, 581-586.

120. Long, Z.; Nugent, E.; Javer, A.; Cicuta, P.; Sclavi, B.; Cosentino Lagomarsino, M.; Dorfman, K.D. Microfluidic chemostat for measuring single cell dynamics in bacteria. Lab Chip 2013, 13, 947-954.

121. Bell, L.; Seshia, A.; Lando, D.; Laue, E.; Palayret, M.; Lee, S.F.; Klenerman, D. A microfluidic device for the hydrodynamic immobilisation of living fission yeast cells for super-resolution imaging. Sens. Actuators B Chem. 2014, 192, 36-41. 
122. Wang, P.; Robert, L.; Pelletier, J.; Dang, W.L.; Taddei, F.; Wright, A.; Jun, S. Robust growth of Escherichia coli. Curr. Biol. 2010, 20, 1099-1103.

123. Balaban, N.Q.; Merrin, J.; Chait, R.; Kowalik, L.; Leibler, S. Bacterial persistence as a phenotypic switch. Science 2004, 305, 1622-1625.

124. Park, J.Y.; Morgan, M.; Sachs, A.N.; Samorezov, J.; Teller, R.; Shen, Y.; Pienta, K.J.; Takayama, S. Single cell trapping in larger microwells capable of supporting cell spreading and proliferation. Microfluid. Nanofluidics 2010, 8, 263-268.

125. Cookson, S.; Ostroff. N.; Pang, W.L.; Volfson, D.; Hasty, J. Monitoring dynamics of single-cell gene expression over multiple cell cycles. Mol. Syst. Biol. 2005, 1, 0024.

126. Bennett, M.R.; Pang, W.L.; Ostroff, N.A.; Baumgartner, B.L.; Nayak, S.; Tsimring, L.S.; Hasty, J. Metabolic gene regulation in a dynamically changing environment. Nature 2008, 454, 1119-1122.

127. Nilsson, J.; Evander, M.; Hammarström, B.; Laurell, T. Review of cell and particle trapping in microfluidic systems. Anal. Chim. Acta 2009, 649, 141-157.

128. Cai, L.; Friedman, N.; Xie, X.S. Stochastic protein expression in individual cells at the single molecule level. Nature 2006, 440, 358-362.

129. Di Carlo, D.; Wu, L.Y.; Lee, L.P. Dynamic single cell culture array. Lab Chip 2006, 6, 1445-1449.

130. Skelley, A.M.; Kirak, O.; Suh, H.; Jaenisch, R.; Voldman, J. Microfluidic control of cell pairing and fusion. Nat. Methods 2009, 6, 147-152.

131. Roach, K.L.; King, K.R.; Uygun, B.E.; Kohane, I.S.; Yarmush, M.L.; Toner, M. High throughput single cell bioinformatics. Biotechnol. Prog. 2009, 25, 1772-1779.

132. Pai, J.H.; Wang, Y.; Salazar, G.T.; Sims, C.E.; Bachman, M.; Li, G.P.; Allbritton, N.L. Photoresist with low fluorescence for bioanalytical applications. Anal. Chem. 2007, 79, 8774-8780.

133. Shadpour, H.; Zawistowski, J.S.; Herman, A.; Hahn, K.; Allbritton, N.L. Patterning pallet arrays for cell selection based on high-resolution measurements of fluorescent biosensors. Anal. Chim. Acta 2011, 696, 101-107.

134. Karp, J.M.; Yeh, J.; Eng, G.; Fukuda, J.; Blumling, J.; Suh, K.Y.; Cheng, J.; Mahdavi, A.; Borenstein, J.; Langer, R.; et al. Controlling size, shape and homogeneity of embryoid bodies using poly(ethylene glycol) microwells. Lab Chip 2007, 7, 786-794.

135. Yamamura, S.; Kishi, H.; Tokimitsu, Y.; Kondo, S.; Honda, R.; Rao, S.R.; Omori, M.; Tamiya, E.; Muraguchi, A. Single-cell microarray for analyzing cellular response. Anal. Chem. 2005, 77, 8050-8056.

136. Taylor, L.C.; Walt, D.R. Application of high-density optical microwell arrays in a live-cell biosensing system. Anal. Biochem. 2000, 278, 132-142.

137. Deutsch, M.; Deutsch, A.; Shirihai, O.; Hurevich, I.; Afrimzon, E.; Shafran, Y.; Zurgil, N. A novel miniature cell retainer for correlative high-content analysis of individual untethered non-adherent cells. Lab Chip 2006, 6, 995-1000.

138. Chin, V.I.; Taupin, P.; Sanga, S.; Scheel, J.; Gage, F.H.; Bhatia, S.N. Microfabricated platform for studying stem cell fates. Biotechnol. Bioeng. 2004, 88, 399-415.

139. Ostuni, E.; Chen, C.S.; Ingber, D.E.; Whitesides, G.M. Selective deposition of proteins and cells in arrays of microwells. Langmuir 2001, 17, 2828-2834.

140. Wang, Y.; Salazar, G.T.; Pai, J.H.; Shadpour, H.; Sims, C.E.; Allbritton, N.L. Micropallet arrays with poly(ethylene glycol) walls. Lab Chip 2008, 8, 734-740. 
141. Kang, L.; Hancock, M.J.; Brigham, M.D.; Khademhosseini, A. Cell confinement in patterned nanoliter droplets in a microwell array by wiping. J. Biomed. Mater. Res. A 2010, 93, 547-557.

142. Barbulovic-Nad, I.; Lucente, M.; Sun, Y.; Zhang, M.; Wheeler, A.R.; Bussmann, M. Bio-microarray fabrication techniques--a review. Crit. Rev. Biotechnol. 2006, 26, 237-259.

143. Guillemot, F.; Souquet, A.; Catros, S.; Guillotin, B.; Lopez, J.; Faucon, M.; Pippenger, B.; Bareille, R.; Rémy, M.; Bellance, S.; et al. High-throughput laser printing of cells and biomaterials for tissue engineering. Acta Biomater. 2010, 6, 2494-2500.

144. Schaack, B.; Reboud, J.; Combe, S.; Fouqué, B.; Berger, F.; Boccard, S.; Filhol-Cochet, O.; Chatelain, F.A. "DropChip" cell array for DNA and siRNA transfection combined with drug screening. NanoBiotech 2005, 1, 183-189.

145. Xu, T.; Jin, J.; Gregory, C.; Hickman, J.J.; Boland, T. Inkjet printing of viable mammalian cells. Biomaterials 2005, 26, 93-99.

146. Ringeisen, B.R.; Othon, C.M.; Barron, J.A.; Young, D.; Spargo, B.J. Jet-based methods to print living cells. Biotechnol. J. 2006, 1, 930-948.

147. Roth, E.A.; Xu, T.; Das, M.; Gregory, C.; Hickman, J.J.; Boland, T. Inkjet printing for high-throughput cell patterning. Biomaterials 2004, 25, 3707-3715.

148. Guillemot, F.; Mironov, V.; Nakamura, M. Bioprinting is coming of age: Report from the International Conference on Bioprinting and Biofabrication in Bordeaux (3B'09). Biofabrication 2010, 2, 010201.

149. Ferris, C.J.; Gilmore, K.G.; Wallace, G.G. In het Panhuis, M. Biofabrication: An overview of the approaches used for printing of living cells. Appl. Microbiol. Biotechnol. 2013, 97, 4243-4258.

150. Narayanaswamy, R.; Niu, W.; Scouras, A.D.; Hart, G.T.; Davies, J.; Ellington, A.D.; Iyer, V.R.; Marcotte, E.M. Systematic profiling of cellular phenotypes with spotted cell microarrays reveals mating-pheromone response genes. Genome Biol. 2006, 7, R6.

151. Zhao, J.; Niu, W.; Yao, J.; Mohr, S.; Marcotte, E.M.; Lambowitz, A.M. Group II intron protein localization and insertion sites are affected by polyphosphate. PLoS Biol. 2008, 6, e150.

152. Hart, T.; Zhao, A.; Garg, A.; Bolusani, S.; Marcotte, E.M. Human cell chips: Adapting DNA microarray spotting technology to cell-based imaging assays. PLOS ONE 2009, 4, e7088.

153. Odde, D.J.; Renn, M.J. Laser-guided direct writing for applications in biotechnology. Trends Biotechnol. 1999, 17, 385-389.

154. Nahmias, Y.; Odde, D.J. Micropatterning of living cells by laser-guided direct writing: Application to fabrication of hepatic-endothelial sinusoid-like structures. Nat. Protoc. 2006, 1, 2288-2296.

155. Tasoglu, S.; Demirci, U. Bioprinting for stem cell research. Trends Biotechnol. 2013, 31, 10-19.

156. Wu, P.K.; Ringeisen, B.R.; Callahan, J.; Brooks, M.; Bubb, D.M.; Wu, H.D.; Piqué, A.; Spargo, B.; McGill, R.A.; Chrisey, D.B. The deposition, structure, pattern deposition, and activity of biomaterial thin-films by matrix-assisted pulsed-laser evaporation (MAPLE) and MAPLE direct write. Thin Solid Films 2001, 398-399, 607-614.

157. Barron, J.A.; Rosen, R.; Jones-Meehan, J.; Spargo, B.J.; Belkin, S.; Ringeisen, B.R. Biological laser printing of genetically modified Escherichia coli for biosensor applications. Biosens. Bioelectron. 2004, 15, 246-252.

158. Barron, J.A.; Wu, P.; Ladouceur, H.D.; Ringeisen, B.R. Biological laser printing: A novel technique for creating heterogeneous 3-dimensional cell patterns. Biomed. Microdevices 2004, 6, 139-147. 
159. Guillotin, B.; Souquet, A.; Catros, S.; Duocastella, M.; Pippenger, B.; Bellance, S.; Bareille, R.; Rémy, M.; Bordenave, L.; Amédée, J.; et al. Laser assisted bioprinting of engineered tissue with high cell density and microscale organization. Biomaterials 2010, 31, 7250-7256.

160. Schiele, N.R.; Chrisey, D.B.; Corr, D.T. Gelatin-based laser direct-write technique for the precise spatial patterning of cells. Tissue Eng. Part C Methods 2011, 17, 289-298.

161. Schiele, N.R.; Corr, D.T.; Huang, Y.; Raof, N.A.; Xie, Y.; Chrisey, D.B. Laser-based direct-write techniques for cell printing. Biofabrication 2010, 2, 032001.

162. Demirci, U.; Montesano, G. Single cell epitaxy by acoustic picolitre droplets. Lab Chip 2007, 7, 1139-1145.

163. Wong, E.Y.; Diamond, S.L. Advancing microarray assembly with acoustic dispensing technology. Anal. Chem. 2009, 81, 509-514.

164. Fang, Y.; Frampton, J.P.; Raghavan, S.; Sabahi-Kaviani, R.; Luker, G.; Deng, C.X.; Takayama, S. Rapid generation of multiplexed cell cocultures using acoustic droplet ejection followed by aqueous two-phase exclusion patterning. Tissue Eng. Part C Methods 2012, 18, 647-657.

165. Torr, G.R. The acoustic radiation force. Am. J. Phys. 1984, 52, 402-408.

166. Elrod, S.A.; Hadimioglu, B.; Khuri-Yakub, B.T.; Rawson, E.G.; Richley, E.; Quate, C.F.; Mansour, N.N.; Lundgren, T.S. Nozzleless droplet formation with focused acoustic beams. J. Appl. Phys. 1989, 65, 3441-3447.

167. Shi, J.; Ahmed, D.; Mao, X.; Lin, S.C.; Lawit, A.; Huang, T.J. Acoustic tweezers: Patterning cells and microparticles using standing surface acoustic waves (SSAW). Lab Chip 2009, 9, 2890-2895.

168. Ding, X.; Lin, S.C.; Kiraly, B.; Yue, H.; Li, S.; Chiang, I.K.; Shi, J.; Benkovic, S.J.; Huang, T.J. On-chip manipulation of single microparticles, cells, and organisms using surface acoustic waves. Proc. Natl. Acad. Sci. USA 2012, 109, 11105-11109.

169. Demirci, U.; Montesano, G. Cell encapsulating droplet vitrification. Lab Chip 2007, 7, 1428-1433.

170. Song, Y.S.; Adler, D.; Xu, F.; Kayaalp, E.; Nureddin, A.; Anchan, R.M.; Maas, R.L.; Demirci, U. Vitrification and levitation of a liquid droplet on liquid nitrogen. Proc. Natl. Acad. Sci. USA 2010 , 107, 4596-4600.

171. Moon, S.; Kim, Y.G.; Dong, L.; Lombardi, M.; Haeggstrom, E.; Jensen, R.V.; Hsiao, L.L.; Demirci, U. Drop-on-demand single cell isolation and total RNA analysis. PLoS ONE 2011, 6, e17455.

172. Allen, J.W.; Khetani, S.R.; Bhatia, S.N. In vitro zonation and toxicity in a hepatocyte bioreactor. Toxicol. Sci. 2005, 84, 110-119.

173. Kane, B.J.; Zinner, M.J.; Yarmush, M.L.; Toner, M. Liver-specific functional studies in a microfluidic array of primary mammalian hepatocytes. Anal. Chem. 2006, 78, 4291-4298.

174. Lee, J.N.; Jiang, X.; Ryan, D.; Whitesides, G.M. Compatibility of mammalian cells on surfaces of poly(dimethylsiloxane). Langmuir 2004, 20, 11684-11691.

175. Stangegaard, M.; Petronis, S.; Jørgensen, A.M.; Christensen, C.B.; Dufva, M. A biocompatible micro cell culture chamber (microCCC) for the culturing and on-line monitoring of eukaryote cells. Lab Chip 2006, 6, 1045-1051.

176. Brischwein, M.; Motrescu, E.R.; Cabala, E.; Otto, A.M.; Grothe, H.; Wolf, B. Functional cellular assays with multiparametric silicon sensor chips. Lab Chip 2003, 3, 234-240. 
177. Peterman, M.C.; Mehenti, N.Z.; Bilbao, K.V.; Lee, C.J.; Leng, T.; Noolandi, J.; Bent, S.F.; Blumenkranz, M.S.; Fishman, H.A. The Artificial Synapse Chip: A flexible retinal interface based on directed retinal cell growth and neurotransmitter stimulation. Artif. Organs 2003, 27, 975-985.

178. Anderson, D.G.; Levenberg, S.; Langer, R. Nanoliter-scale synthesis of arrayed biomaterials and application to human embryonic stem cells. Nat. Biotechnol. 2004, 22, 863-866.

179. Bettinger, C.J.; Weinberg, E.J.; Kulig, K.M.; Vacanti, J.P.; Wang, Y.; Borenstein, J.T.; Langer, R. Three-dimensional microfluidic tissue-engineering scaffolds using a flexible biodegradable polymer. Adv. Mater. 2005, 18, 165-169.

180. Radhakrishnan, R.; Solomon, M.; Satyamoorthy, K.; Martin, L.E.; Lingen, M.W. Tissue microarray-a high-throughput molecular analysis in head and neck cancer. J. Oral Pathol. Med. 2008, 37, 166-176.

181. Gu, W.; Zhu, X.; Futai, N.; Cho, B.S.; Takayama, S. Computerized microfluidic cell culture using elastomeric channels and Braille displays. Proc. Natl. Acad. Sci. USA 2004, 101, 15861-1586.

182. Burks, G.A.; Velegol, S.B.; Paramonova, E.; Lindenmuth, B.E.; Feick, J.D.; Logan, B.E. Macroscopic and nanoscale measurements of the adhesion of bacteria with varying outer layer surface composition. Langmuir 2003, 19, 2366-2371.

183. Katsikogianni, M.G.; Missirlis, Y.F. Bacterial adhesion onto materials with specific surface chemistries under flow conditions. J. Mater. Sci. Mater. Med. 2010, 21, 963-968.

184. Kasas, S.; Ruggeri, F.S.; Benadiba, C.; Maillard, C.; Stupar, P.; Tournu, H.; Dietler, G.; Longo, G. Detecting nanoscale vibrations as signature of life. Proc. Natl. Acad. Sci. USA 2015, 112, 378-381.

185. Ming, F.; Eisenthal, R.; Whish, W.J.; Hubble, J. The kinetics of affinity-mediated cell-surface attachment. Enzym. Microb. Technol. 2000, 26, 216-221.

186. Uhlendorf, J.; Miermont, A.; Delaveau, T.; Charvin, G.; Fages, F.; Bottani, S.; Batt, G.; Hersen, P. Long-term model predictive control of gene expression at the population and single-cell levels. Proc. Natl. Acad. Sci. USA 2012, 109, 14271-14276.

187. Yamazoe, H.; Tanabe, T. Cell micropatterning on an albumin-based substrate using an inkjet printing technique. J. Biomed. Mater. Res. A 2009, 91, 1202-1209.

188. Douglas, E.S.; Chandra, R.A.; Bertozzi, C.R.; Mathies, R.A.; Francis, M.B. Self-assembled cellular microarrays patterned using DNA barcodes. Lab Chip 2007, 7, 1442-1448.

189. Chen, C.S.; Mrksich, M.; Huang, S.; Whitesides, G.M.; Ingber, D.E. Geometric control of cell life and death. Science 1997, 276, 1425-1428.

190. Degot, S.; Auzan, M.; Chapuis, V.; Béghin, A.; Chadeyras, A.; Nelep, C.; Calvo-Muñoz, M.L.; Young, J.; Chatelain, F.; Fuchs, A. Improved visualization and quantitative analysis of drug effects using micropatterned cells. J. Vis. Exp. 2010, 46, 2514.

191. Schauer, K.; Duong, T.; Bleakley, K.; Bardin, S.; Bornens, M.; Goud, B. Probabilistic density maps to study global endomembrane organization. Nat. Methods 2010, 7, 560-566.

192. Bhatia, S.N.; Yarmush, M.L.; Toner, M. Controlling cell interactions by micropatterning in co-cultures: Hepatocytes and 3 T3 fibroblasts. J. Biomed. Mater. Res. 1997, 34, 189-199.

193. Wang, X.; Song, W.; Kawazoe, N.; Chen, G. The osteogenic differentiation of mesenchymal stem cells by controlled cell-cell interaction on micropatterned surfaces. J. Biomed. Mater. Res. A 2013, $101,3388-3395$. 
194. Bhadriraju, K.; Chen, C.S. Engineering cellular microenvironments to improve cell-based drug testing. Drug Discov. Today 2002, 7, 612-620.

195. De Gans, B.J.; Schubert, U.S. Inkjet printing of polymer micro-arrays and libraries: Instrumentation, requirements, and perspectives. Macromol. Rapid Commun. 2003, 24, 659-666.

196. Kovarik, M.L.; Gach, P.C.; Ornoff, D.M.; Wang, Y.; Balowski, J.; Farrag, L.; Allbritton, N.L. Micro total analysis systems for cell biology and biochemical assays. Anal. Chem. 2012, 84, 516-540.

197. Quake, S.R.; Scherer, A. From micro- to nanofabrication with soft materials. Science 2000, 290, 1536-1540.

198. Thorsen, T.; Maerkl, S.J.; Quake, S.R. Microfluidic large-scale integration. Science 2002, 298, $580-584$.

199. Melin, J.; Quake, S.R. Microfluidic large-scale integration: The evolution of design rules for biological automation. Annu. Rev. Biophys. Biomol. Struct. 2007, 36, 213-231.

200. Groisman, A.; Enzelberger, M.; Quake, S.R. Microfluidic memory and control devices. Science 2003, 300, 955-958.

201. Toepke, M.W.; Abhyankar, V.V.; Beebe, D.J. Microfluidic logic gates and timers. Lab Chip 2007, 7, 1449-1453.

202. Dénervaud, N.; Becker, J.; Delgado-Gonzalo, R.; Damay, P.; Rajkumar, A.S.; Unser, M.; Shore, D.; Naef, F.; Maerkl, S.J. A chemostat array enables the spatio-temporal analysis of the yeast proteome. Proc. Natl. Acad. Sci. USA 2013, 110, 15842-15847.

203. Leibacher, I.; Schoendube, J.; Dual, J.; Zengerle, R.; Koltay, P. Enhanced single-cell printing by acoustophoretic cell focusing. Biomicrofluidics 2015, 9, 024109.

204. Lee, P.J.; di Carlo, D. Single cell analysis for quantitative systems biology. In Single Cell Analysis: Technologies and Applications; Anselmetti, D., Ed.; Wiley-VCH Verlag GmbH \& Co.: Weinheim, Germany, 2009; pp. 135-160.

205. Rao, C.V.; Wolf, D.M.; Arkin, A.P. Control, exploitation and tolerance of intracellular noise. Nature 2002, 420, 231-237.

206. Lidstrom, M.E.; Meldrum, D.R. Life-on-a-chip. Nat. Rev. Microbiol. 2003, 1, 158-164.

207. Sigal, A.; Milo, R.; Cohen, A.; Geva-Zatorsky, N.; Klein, Y.; Liron, Y.; Rosenfeld, N.; Danon, T.; Perzov, N.; Alon, U. Variability and memory of protein levels in human cells. Nature 2006, 444, 643-646.

208. Newman, J.R.; Ghaemmaghami, S.; Ihmels, J.; Breslow, D.K.; Noble, M.; DeRisi, J.L.; Weissman, J.S. Single-cell proteomic analysis of $S$. cerevisiae reveals the architecture of biological noise. Nature 2006, 441, 840-846.

209. Yu, J.; Xiao, J.; Ren, X.; Lao, K.; Xie, X.S. Probing gene expression in live cells, one protein molecule at a time. Science 2006, 311, 1600-1603.

210. Elowitz, M.B.; Levine, A.J.; Siggia, E.D.; Swain, P.S. Stochastic gene expression in a single cell. Science 2002, 297, 1183-1186.

211. Levsky, J.M.; Singer, R.H. Gene expression and the myth of the average cell. Trends Cell Biol. 2003, 13, 4-6.

212. Lahav, G.; Rosenfeld, N.; Sigal, A.; Geva-Zatorsky, N.; Levine, A.J.; Elowitz, M.B.; Alon, U. Dynamics of the p53-Mdm2 feedback loop in individual cells. Nat. Genet. 2004, 36, 147-150. 
213. Lidstrom, M.E.; Konopka, M.C. The role of physiological heterogeneity in microbial population behavior. Nat. Chem. Biol. 2010, 6, 705-712.

214. Wang, D.; Bodovitz, S. Single cell analysis: The new frontier in "omics". Trends Biotechnol. 2010, 28, 281-290.

215. Raser, J.M.; O'Shea, E.K. Noise in gene expression: Origins, consequences, and control. Science 2005, 309, 2010-2013.

216. Rosenfeld, N.; Young, J.W.; Alon, U.; Swain, P.S.; Elowitz, M.B. Gene regulation at the single-cell level. Science 2005, 307, 1962-195.

217. Mettetal, J.T.; Muzzey, D.; Pedraza, J.M.; Ozbudak, E.M.; van Oudenaarden, A. Predicting stochastic gene expression dynamics in single cells. Proc. Natl. Acad. Sci. USA 2006, 103, 7304-7309.

218. Bhalla, U.S. Signaling in small subcellular volumes. I. Stochastic and diffusion effects on individual pathways. Biophys. J. 2004, 87, 733-744.

219. Kholodenko, B.N.; Hancock, J.F.; Kolch, W. Signalling ballet in space and time. Nat. Rev. Mol. Cell Biol. 2010, 11, 414-426.

220. Le Gac, S.; van den Berg, A. Single cells as experimentation units in lab-on-a-chip devices. Trends Biotechnol. 2010, 28, 55-62.

221. Wang, Y.; Chen, Z.Z.; Li, Q. Microfluidic techniques for dynamic single-cell analysis. Microchim. Acta 2010, 168, 177-195.

222. Walling, M.A.; Shepard, J.R. Cellular heterogeneity and live cell arrays. Chem. Soc. Rev. 2011, 40, 4049-4076.

223. Yin, H.; Marshall, D. Microfluidics for single cell analysis. Curr. Opin. Biotechnol. 2012, 23, 110-119.

224. Dusny, C.; Schmid, A. Microfluidic single-cell analysis links boundary environments and individual microbial phenotypes. Environ. Microbiol. 2015, 17, 1839-1856.

225. Junkin, M.; Tay, S. Microfluidic single-cell analysis for systems immunology. Lab Chip 2014, 14, 1246-1260.

226. Pedraza, J.M.; van Oudenaarden, A. Noise propagation in gene networks. Science 2005, 307, 1965-1969.

227. Charvin, G.; Cross, F.R.; Siggia, E.D. A microfluidic device for temporally controlled gene expression and long-term fluorescent imaging in unperturbed dividing yeast cells. PLoS ONE 2008, 3, e1468.

228. Charvin, G.; Cross, F.R.; Siggia, E.D. Forced periodic expression of G1 cyclins phase-locks the budding yeast cell cycle. Proc. Natl. Acad. Sci. USA 2009, 106, 6632-6637.

229. Rowat, A.C.; Bird, J.C.; Agresti, J.J.; Rando, O.J.; Weitz, D.A. Tracking lineages of single cells in lines using a microfluidic device. Proc. Natl. Acad. Sci. USA 2009, 106, 18149-18154.

230. Howson, R.; Huh, W.K.; Ghaemmaghami S.; Falvo, J.V.; Bower, K.; Belle, A.; Dephoure, N.; Wykoff, D.D.; Weissman, J.S.; O'Shea, E.K. Construction, verification and experimental use of two epitope-tagged collections of budding yeast strains. Comp. Funct. Genomics 2005, 6, 2-16.

231. Cohen, A.A.; Geva-Zatorsky, N.; Eden, E.; Frenkel-Morgenstern, M.; Issaeva, I.; Sigal, A.; Milo, R.; Cohen-Saidon, C.; Liron, Y.; Kam, Z.; et al. Dynamic proteomics of individual cancer cells in response to a drug. Science 2008, 322, 1511-1516. 
232. Taylor, D.L.; Haskins, J.R.; Giuliano, K. (Eds.) High Content Screening: A Powerful Approach to Systems Cell Biology and Drug Discovery; Humana Press: Totowa, NJ, USA, 2007.

233. Haney, S.A. (Ed.) High Content Screening: Science, Techniques, and Applications; John Wiley\&Sons: Hoboken, NJ, USA, 2008.

234. Lipp, P.; Kaestner, L. Image-based high-content screening-a view from basic sciences. In High-Throughput Screening in Drug Discovery; Hüser, J., Ed.; Wiley VCH: Weinheim, Germany, 2006; pp. 129-149.

235. Huh, W.K.; Falvo, J.V.; Gerke, L.C.; Carroll, A.S.; Howson, R.W.; Weissman, J.S.; O’Shea, E.K. Global analysis of protein localization in budding yeast. Nature 2003, 425, 686-691.

236. Conrad, C.; Erfle, H.; Warnat, P.; Daigle, N.; Lörch, T.; Ellenberg, J.; Pepperkok, R.; Eils, R. Automatic identification of subcellular phenotypes on human cell arrays. Genome Res. 2004, 14, $1130-1136$.

237. Saito, T.L.; Ohtani, M.; Sawai, H.; Sano, F.; Saka, A.; Watanabe, D.; Yukawa, M.; Ohya, Y.; Morishita, S. SCMD: Saccharomyces cerevisiae Morphological Database. Nucleic Acids Res. 2004, 32, D319-D322.

238. Vaisberg, E.A.; Lenzi, D.; Hansen, R.L.; Keon, B.H.; Finer, J.T. An infrastructure for high-throughput microscopy: Instrumentation, informatics, and integration. Methods Enzymol. 2006, 414, 484-512.

239. Loo, L.H.; Wu, L.F.; Altschuler, S.J. Image-based multivariate profiling of drug responses from single cells. Nat. Methods 2007, 4, 445-453.

240. Carpenter, A.E. Image-based chemical screening. Nat. Chem. Biol. 2007, 3, 461-465.

241. Locke, J.C.; Elowitz, M.B. Using movies to analyse gene circuit dynamics in single cells. Nat. Rev. Microbiol. 2009, 7, 383-392.

242. Taniguchi, Y.; Choi, P.J.; Li, G.W.; Chen, H.; Babu, M.; Hearn, J.; Emili, A.; Xie, X.S. Quantifying E. coli proteome and transcriptome with single-molecule sensitivity in single cells. Science $\mathbf{2 0 1 0}$, $329,533-538$.

243. Derveaux, S.; Stubbe, B.G.; Braeckmans, K.; Roelant, C.; Sato, K.; Demeester, J.; de Smedt, S.C. Synergism between particle-based multiplexing and microfluidics technologies may bring diagnostics closer to the patient. Anal. Bioanal. Chem. 2008, 391, 2453-2467.

244. Situma, C.; Hashimoto, M.; Soper, S.A. Merging microfluidics with microarray-based bioassays. Biomol. Eng. 2006, 23, 213-231.

245. Lombardi, D.; Dittrich, P.S. Advances in microfluidics for drug discovery. Expert Opin. Drug Discov. 2010, 5, 1081-1094.

246. Wlodkowic, D.; Cooper, J.M. Microfluidic cell arrays in tumor analysis: New prospects for integrated cytomics. Expert Rev. Mol. Diagn. 2010, 10, 521-530.

247. Marimuthu, M.; Kim, S. Microfluidic cell coculture methods for understanding cell biology, analyzing bio/pharmaceuticals, and developing tissue constructs. Anal. Biochem. 2011, 413, 81-89.

248. Neuži, P.; Giselbrecht, S.; Länge, K.; Huang, T.J.; Manz, A. Revisiting lab-on-a-chip technology for drug discovery. Nat. Rev. Drug Discov. 2012, 11, 620-632.

249. Zheng, X.T.; Yu, L.; Li, P.; Dong, H.; Wang, Y.; Liu, Y.; Li, C.M. On-chip investigation of cell-drug interactions. Adv. Drug Deliv. Rev. 2013, 65, 1556-1574. 
250. Xu, F.; Wu, J.; Wang, S.; Durmus, N.G.; Gurkan, U.A.; Demirci, U. Microengineering methods for cell-based microarrays and high-throughput drug-screening applications. Biofabrication 2011, 3, 034101.

251. Angres, B. Cell microarrays. Expert Rev. Mol. Diagn. 2005, 5, 769-779.

252. Kumar, P.T.; Vriens, K.; Cornaglia, M.; Gijs, M.; Kokalj, T.; Thevissen, K.; Geeraerd, A.; Cammue, B.P.; Puers, R.; Lammertyn, J. Digital microfluidics for time-resolved cytotoxicity studies on single non-adherent yeast cells. Lab Chip 2015, 15, 1852-1860.

253. Pasirayi, G.; Scott, S.M.; Islam, M.; O’Hare, L.; Bateson, S.; Ali, Z. Low cost microfluidic cell culture array using normally closed valves for cytotoxicity assay. Talanta 2014, 129, 491-498.

254. Li, N.; Tourovskaia, A.; Folch, A. Biology on a chip: Microfabrication for studying the behavior of cultured cells. Crit. Rev. Biomed. Eng. 2003, 31, 423-488.

255. Meyvantsson, I.; Beebe, D.J. Cell culture models in microfluidic systems. Annu. Rev. Anal. Chem. (Palo Alto Calif.) 2008, 1, 423-449.

256. Salieb-Beugelaar, G.B.; Simone, G.; Arora, A.; Philippi, A.; Manz, A. Latest developments in microfluidic cell biology and analysis systems. Anal. Chem. 2010, 82, 4848-4864.

257. Berthuy, O.I.; Blum, L.J.; Marquette, C.A. Cells on chip for multiplex screening. Biosens. Bioelectron. 2015, doi:10.1016/j.bios.2015.04.024.

258. Cambier, T.; Honegger, T.; Vanneaux, V.; Berthier, J.; Peyrade, D.; Blanchoin, L.; Larghero, J.; Théry, M. Design of a 2D no-flow chamber to monitor hematopoietic stem cells. Lab Chip 2015, $15,77-85$.

259. Lattermann, C.; Büchs, J. Microscale and miniscale fermentation and screening. Curr. Opin. Biotechnol. 2014, 23, 1-6.

260. Marques, M.P.; Fernandes, P. Microfluidic devices: Useful tools for bioprocess intensification. Molecules 2011, 16, 8368-8401.

261. Love, K.R.; Panagiotou, V.; Jiang, B.; Stadheim, T.A.; Love, J.C. Integrated single-cell analysis shows Pichia pastoris secretes protein stochastically. Biotechnol. Bioeng. 2010, 106, 319-325.

262. Dai, J.; Yoon, S.H.; Sim, H.Y.; Yang, Y.S.; Oh, T.K.; Kim, J.F.; Hong, J.W. Charting microbial phenotypes in multiplex nanoliter batch bioreactors. Anal. Chem. 2013, 85, 5892-5899.

263. Grünberger, A.; Wiechert, W.; Kohlheyer, D. Single-cell microfluidics: Opportunity for bioprocess development. Curr. Opin. Biotechnol. 2014, 29, 15-23.

264. Mustafi, N.; Grünberger, A.; Mahr, R.; Helfrich, S.; Nöh, K.; Blombach, B.; Kohlheyer, D.; Frunzke, J. Application of a genetically encoded biosensor for live cell imaging of L-valine production in pyruvate dehydrogenase complex-deficient Corynebacterium glutamicum strains. PLoS ONE 2014, 9, e85731.

265. Unthan, S.; Grünberger, A.; van Ooyen, J.; Gätgens, J.; Heinrich, J.; Paczia, N.; Wiechert, W.; Kohlheyer, D.; Noack, S. Beyond growth rate 0.6: What drives Corynebacterium glutamicum to higher growth rates in defined medium. Biotechnol. Bioeng. 2014, 111, 359-371.

266. El-Ali, J.; Sorger, P.K.; Jensen, K.F. Cells on chips. Nature 2006, 442, 403-411.

267. Szita, N.; Boccazzi, P.; Zhang, Z.; Boyle, P.; Sinskey, A.J.; Jensen, K.F. Development of a multiplexed microbioreactor system for high-throughput bioprocessing. Lab Chip 2005, 5, 819-826. 
268. Boccazzi, P.; Zanzotto, A.; Szita, N.; Bhattacharya, S.; Jensen, K.F.; Sinskey, A.J. Gene expression analysis of Escherichia coli grown in miniaturized bioreactor platforms for high-throughput analysis of growth and genomic data. Appl. Microbiol. Biotechnol. 2005, 68, 518-532.

269. Ziolkowska, K.; Jedrych, E.; Kwapiszewski, R.; Lopacinska, J.M.; Skolimowski, M.; Chudy, M. PDMS/glass microfluidic cell culture system for cytotoxicity tests and cells passage. Sens. Actuators B: Chem. 2010, 145, 533-542.

270. Li, X.; Xue, X.; Li, P.C. Real-time detection of the early event of cytotoxicity of herbal ingredients on single leukemia cells studied in a microfluidic biochip. Integr. Biol. (Camb.) 2009, 1, 90-98.

271. Hosokawa, M.; Hayashi, T.; Mori, T.; Yoshino, T.; Nakasono, S.; Matsunaga, T. Microfluidic device with chemical gradient for single-cell cytotoxicity assays. Anal. Chem. 2011, 83, 3648-3654.

272. Chanasakulniyom, M.; Glidle, A.; Cooper, J.M. Cell proliferation and migration inside single cell arrays. Lab Chip 2015, 15, 208-215.

273. Thompson, D.M.; King, K.R.; Wieder, K.J.; Toner, M.; Yarmush, M.L.; Jayaraman, A. Dynamic gene expression profiling using a microfabricated living cell array. Anal. Chem. 2004, 76, 4098-4103.

274. Kim, L.; Vahey, M.D.; Lee, H.Y.; Voldman, J. Microfluidic arrays for logarithmically perfused embryonic stem cell culture. Lab Chip 2006, 6, 394-406.

275. Park, M.C.; Hur, J.Y.; Cho, H.S.; Park, S.H.; Suh, K.Y. High-throughput single-cell quantification using simple microwell-based cell docking and programmable time-course live-cell imaging. Lab Chip 2011, 11, 79-86.

276. Grünberger, A.; Paczia, N.; Probst, C.; Schendzielorz, G.; Eggeling, L.; Noack, S.; Wiechert, W.; Kohlheyer, D. A disposable picolitre bioreactor for cultivation and investigation of industrially relevant bacteria on the single cell level. Lab Chip 2012, 12, 2060-2068.

277. Zhang, B.; Kim, M.C.; Thorsen, T.; Wang, Z. A self-contained microfluidic cell culture system. Biomed. Microdevices 2009, 11, 1233-1237.

278. Gottschamel, J.; Richter, L.; Mak, A.; Jungreuthmayer, C.; Birnbaumer, G.; Milnera, M.; Brückl, H.; Ertl, P. Development of a disposable microfluidic biochip for multiparameter cell population measurements. Anal. Chem. 2009, 81, 8503-8512.

(C) 2015 by the authors; licensee MDPI, Basel, Switzerland. This article is an open access article distributed under the terms and conditions of the Creative Commons Attribution license (http://creativecommons.org/licenses/by/4.0/). 